\title{
URGENSI PENGATURAN STRICT LIABILITY DALAM RANCANGAN AMANDEMEN UNDANG-UNDANG PERLINDUNGAN KONSUMEN
}

\author{
Ari Wahyudi Hertanto ${ }^{1}$
}

\begin{abstract}
The core of the product liability were the perpetrators responsible for the damage, disability, explanations, discomfort and suffering experienced by consumers due to the use or consume goods or services it produces. Product Liability is generally also called product liability, accountability of product, or responsibility of the manufacturer. In practice, the adage that states that the consumer as a buyer should be prudent (caveat emptor) is still very relevant. Many constraints faced in realizing these principles in order to be applied fairly and appropriately.
\end{abstract}

Keywords: consumer, strict liability, principle of responsibility

\begin{abstract}
Abstrak
Inti dari product liability adalah pelaku bertanggungjawab atas kerusakan, kecacatan, penjelasan, ketidaknyamanan dan penderitaan yang dialami oleh konsumen karena pemakaian atau mengkonsumsi barang atau jasa yang dihasilkannya. Product Liability umumnya disebut juga dengan istilah tanggung jawab produk, tanggung gugat produk, atau tanggung jawab produsen. Di dalam praktek pun, adagium yang menyatakan bahwa konsumen selaku pembeli harus hati-hati (caveat emptor) masihlah sangat relevan. Banyak kendala-kendala yang dihadapi dalam mewujudkan prinsip tersebut agar dapat diterapkan secara adil dan tepat.
\end{abstract}

Kata kunci: konsumen, strict liability, prinsip tanggungjawab

\section{Latar Belakang}

Kemajuan teknologi pada beberapa dekade terakhir ini yang begitu pesat telah merubah hal-hal yang fundamental di berbagai bidang, termasuk ekonomi. Perdagangan dunia dan sistem informasi yang semakin terbuka mengakibatkan volume transaksi meningkat dengan fantastis. Transaksi dapat dilakukan secara cepat dari satu kota, negara, bahkan lintas benua tanpa harus bertatap muka terlebih

\footnotetext{
${ }^{1}$ Penulis adalah Staf Pengajar FHUI. Alamat kontak: ari_didit@yahoo.com
} 
dahulu. Cara yang lazim dilakukan mulai dipandang sebagai sesuatu yang konvensional dan ketinggalan jaman. Produsen berpacu memproduksi dan menjual hasil produknya ke belahan dunia lain dengan maksud memperoleh keuntungan bagi kelangsungan usahanya.

Tidak terkecuali di Indonesia, iklim usaha semakin ketat yang ditandai dengan persaingan menghasilkan barang yang bermutu baik dan ditunjang dengan pemasaran yang sedemikian rupa. Beberapa tahun terakhir di Indonesia pembangunan ekonomi menjadi prioritas utama dengan sasaran pertumbuhan ekonomi yang tinggi. Pembangunan di bidang ekonomi yang berorientasi pertumbuhan ekonomi yang tinggi tersebut telah menghasilkan konglomerasi di bidang usaha. Namun ironisnya pada saat yang sama ada kepentingan yang terasa belum secara utuh menjadi bagian dari kegiatan bidang ekonomi, yaitu aspek-aspek perlindungan konsumen. Kepentingan konsumen tersebut seolah-olah tertinggal jauh jika dibandingkan dengan kepentingan para pelaku usaha. Keterbatasan pengetahuan atas hak-hak konsumen dan ketidak jelasan peraturan untuk menuntut ganti rugi pada saat konsumen dirugikan akibat mengkonsumsi, menggunakan atau memakai barang dan jasa untuk kebutuhannya menyebabkan konsumen kerap kali menjadi korban sepihak dari arus perpindahan barang ini. Sebaliknya, pelaku usaha yang tidak bertanggung jawab dengan mudah dapat meraup keuntungan besar tanpa harus bertanggung jawab atas apa yang dialami konsumen akibat mengonsumsi barang yang dijualnya. Misalnya terkait dengan mutu barang dan layanan jasa, kalangan pelaku usaha yang tidak bertanggung jawab menempatkannya pada prioritas kedua setelah keuntungan usaha, hal ini terjadi di masyarakat selama bertahun-tahun, sehingga menimbulkan ketimpangan baik sosiologis maupun hukum. ${ }^{2}$

Di pasar bebas, secara klasik pelaku usaha selalu menawarkan produkproduknya, baik yang berupa barang maupun jasa, dengan tujuan untuk mencari keuntungan yang semaksimal mungkin. Namun dilain pihak konsumen pun ingin memperoleh barang dan/atau jasa yang selain murah, sesuai dengan kebutuhan dan

\footnotetext{
${ }^{2}$ Permasalahan yang dihadapi konsumen Indonesia, juga dialami konsumen di negara-negara berkembang lainnya, tidak hanya sekadar bagaimana memilih barang, tetapi jauh lebih kompleks dari itu yaitu menyangkut pada penyadaran semua pihak, baik itu pelaku usaha, pemerintah maupun konsumen tentang pentingnya perlindungan konsumen. Pelaku usaha harus menghargai hak-hak konsumen dengan memproduksi barang dan jasa yang berkualitas, aman dikonsumsi, mengikuti standar yang berlaku, dengan harga yang sesuai (reasonable). Pemerintah menyadari demikian kompleksnya permasalahan yang dihadapi dalam rangka perlindungan konsumen. Peraturan perundang-undangan yang diberlakukan perlu untuk mengatasi permasalahan tersebut tetapi tidak kalah penting juga adalah tugas untuk melaksanakan dan mengawasi penerapan peraturan yang diberlakukan.
} 
juga aman. Pada kenyataannya kedudukan antara pelaku usaha dengan konsumen tidaklah memiliki perimbangan kekuatan yang sama. Posisi pihak pelaku usaha jauh lebih kuat daripada (para) konsumen, khususnya konsumen-konsumen perorangan. Dominasi pelaku usaha tersebut merebak salah satu diantaranya dikarenakan oleh penguasaan produk yang sepenuhnya berada pada produsen. Kondisi semacam ini menyebabkan rentannya eksploitasi konsumen oleh para pelaku usaha. Ketidakkondusifan situasi ini mendorong pemerintah untuk memberlakukan Undangundang Nomor 8 Tahun 1999 Tentang Perlindungan Konsumen ("UUPK"). Pemberlakuan UUPK ini merupakan upaya pemerintah untuk memberikan jaminan kepastian hukum bagi para konsumen, yaitu berupa pemberian perlindungan atas hak-hak dasar konsumen.

Dengan telah diberlakukannya UUPK, maka diharapkan upaya perlindungan konsumen di Indonesia lebih diperhatikan. Pada Pasal 19 sampai dengan Pasal 28 UUPK diatur mengenai tanggung jawab pelaku usaha atas barang yang diproduksinya atau disebut juga dengan product liability. ${ }^{3}$ Pasal 19 ayat (1) menyatakan, bahwa:

Pelaku usaha bertanggung jawab memberikan ganti rugi atas kerusakan, pencemaran, dan/atau kerugian konsumen akibat mengonsumsi barang dan/atau jasa yang dihasilkan atau diperdagangkan.

Selanjutnya diatur lebih jauh mengenai ganti rugi pelaku usaha pada Pasal 19 ayat (2) yang menyatakan, bahwa:

Ganti rugi sebagaimana dimaksud pada ayat (1) dapat berupa pengembalian uang atau penggantian barang dan/atau jasa yang sejenis

${ }^{3}$ Product liability is the area of law in which manufacturers, distributors, suppliers, retailers, and others who make products available to the public are held responsible for the injuries those products cause. Although the word "product" has broad connotations, product liability as an area of law is traditionally limited to products in the form of tangible personal property $<$ http://en.wikipedia.org/wiki/Product_liability>, diakses tanggal 5 Januari 2011.

Product liability in the United States:

1. Theories of liability;

2. Types of liability;

3. Breach of warranty;

4. Negligence;

5. Strict liability;

6. Consumer protection. 
atau setara nilainya, atau perawatan kesehatan dan/atau pemberian santunan yang sesuai dengan ketentuan peraturan perundang-undangan yang berlaku.

Namun demikian pada UUPK Pasal 19 ayat (5) yang yang menyatakan, bahwa:

Ketentuan sebagaimana dimaksud pada ayat (1) dan ayat (2) tidak berlaku apabila pelaku usaha dapat membuktikan bahwa kesalahan tersebut merupakan kesalahan konsumen.

Meskipun demikian jauh sebelum berlakunya UUPK ini, secara yuridis formal prinsip ini sejatinya juga telah diatur dalam beberapa pasal dalam KUH Perdata diantaranya Pasal 1322, 1473, 1474, 1491, 1504 sampai dengan 1511. Walaupun dengan catatan, ruang lingkup materinya tidak se-ekstensif ketentuan yang diatur dalam UUPK. ${ }^{4}$

Selanjutnya ditegaskan pula dalam KUH Perdata pasal 1365, maka bila seorang konsumen menderita kerugian ingin menuntut pihak pelaku usaha (termasuk pedagang, grosir, distributor dan agen), maka pihak korban tersebut akan menghadapi beberapa kendala yang akan menyulitkannya untuk memperoleh ganti rugi. Kesulitan tersebut adalah pihak konsumen harus membuktikan adanya unsur kesalahan yang dilakukan oleh pihak pelaku usaha. Jika konsumen tidak berhasil membuktikan kesalahan produsen, maka gugatan konsumen akan gagal/batal. ${ }^{5}$

Dalam salah satu referensi disebutkan, bahwa agar supaya ketentuan Pasal 1365 KUH Perdata tersebut dapat berlaku, maka tiap-tiap perbuatan atau kealpaan dari seseorang harus ditinjau sendiri-sendiri, sebagai perbuatan atau kealpaan seseorang pribadi hukum (recht subject), dan tak dapat dibeda-bedakan apakah perbuatannya itu timbul oleh sebab ia bertindak sebagai kuasanya orang lain, ataupun bertindak untuk diri-pribadi, sebab yang harus ditinjau ialah kesusilaan atau kepantasannya perbuatannya atau kealpaannya untuk menetapkan kesalahannya

${ }^{4}$ Lihat <http://fh-unsri.info/?p=279>, diakses tanggal 4 Juni 2009.

${ }^{5}$ Lihat pula ketentuan Pasal 19 ayat (3) dan (4) yang menyatakan sebagai berikut:

(3) Pemberian ganti rugi dilaksanakan dalam tenggang waktu 7 (tujuh) hari setelah tanggal transaksi.

(4) Pemberian ganti rugi sebagaimana dimaksud pada ayat (1) dan ayat (2) tidak menghapuskan kemungkinan adanya gugatan pidana berdasarkan pembuktian lebih lanjut mengenai adanya unsur kesalahan. 
(schuld), kesalahan mana hanya dapat diselidiki dan ditetapkan mengenai diri pribadi seseorang itu, dan tidak pada diri pribadi orang yang memberi kuasa kepadanya. ${ }^{6}$

Mengacu pada penjelasan di atas dalam ketentuan pasal-pasal UUPK telah mengatur tentang product liability, ${ }^{7}$ sedangkan dalam rangka dilakukannya proses amandemen UUPK, maka dipandang perlu untuk turut mencantumkan pasal-pasal yang mengatur tentang prinsip tanggung jawab langsung (strict liability) kepada para pelaku usaha atau produsen. Alasan yang melatarbelakangi adalah product liability berdasarkan literatur yang ada merupakan genus, sedangkan salah satu spesiesnya adalah strict liability. ${ }^{8}$ Prinsip tanggung jawab langsung (strict liability) itu sendiri dapat diartikan bahwa pelaku usaha harus bertanggung jawab atas kerugian konsumen tanpa harus membuktikan ada tidaknya kesalahan pada dirinya. Dengan diterapkannya prinsip tanggung jawab mutlak ini, maka setiap konsumen yang merasa dirugikan akibat produk atau barang yang cacat atau tidak aman dapat menuntut kompensasi tanpa harus mempermasalahkan ada atau tidak adanya unsur kesalahan di pihak produsen.

Beberapa pertimbangan yang merupakan tolok ukur berpikir kami adalah dengan diberlakukannya perdagangan bebas ASEAN-China (AC-FTA) ${ }^{9}$ bagi

6 Lihat <http://rgs-yurisprudensi.blogspot.com/2009/04/penerapan-pasal-1365-bw.html>, diakses tanggal 4 Juni 2009.

${ }^{7}$ Loc. Cit., Lihat <http://fh-unsri.info/?p=279> adalah salah satu prinsip yang cukup memberikan angin segar bagi konsumen Indonesia adalah product liability principle yang berusaha menempatkan kedudukan konsumen agar lebih "sederajat" dengan pelaku usaha. Diakses tanggal 4 Juni 2009.

${ }^{8}$ In law, strict liability is a standard for liability which may exist in either a criminal or civil context. A rule specifying strict liability makes a person legally responsible for the damage and loss caused by his or her acts and omissions regardless of culpability (including fault in criminal law terms, typically the presence of mens rea). Strict liability is prominent in tort law (especially product liability), corporations law, and criminal law. For analysis of the pros and cons of strict liability as applied to product liability, the most important strict liability regime, see product liability.

${ }^{9}$ Kesepakatan pembentukan perdagangan bebas ACFTA diawali oleh kesepakatan para peserta ASEAN-China Summit di Brunei Darussalam pada November 2001. Hal tersebut diikuti dengan penandatanganan Naskah Kerangka Kerjasama Ekonomi (The Framework Agreement on a Comprehensive Economic Cooperation) oleh para peserta ASEAN-China Summit di Pnom Penh pada November 2002, dimana naskah ini menjadi landasan bagi pembentukan ACFTA dalam 10 tahun dengan suatu fleksibilitas diberikan kepada negara tertentu seperi Kamboja, Laos; Myanmar dan Vietnam. 
Indonesia pada tahun 2010 ini memberikan ancaman baru bagi upaya perlindungan konsumen di Indonesia. Masuknya berbagai produk asal China akibat kesepakatan penurunan tarif tidak dapat dibendung oleh instrumen proteksi perdagangan. Produkproduk China dengan harga murah karena memiliki keunggulan komparatif dalam proses produksinya kemungkinan akan lebih dipilih oleh konsumen domestik. Kemungkinan meningkatnya pelanggaran terhadap hak-hak konsumen perlu diantisipasi termasuk bentuk tanggung jawab pelaku usaha terhadap kerugian yang diderita oleh konsumen. Penerapan prinsip strict liability mungkin menjadi salah satu bentuk penyelesaian masalah pertanggungjawaban yang dapat mempercepat proses ganti rugi atas kerugian yang dialami konsumen.

Agar prinsip ini dapat diimplementasikan dengan baik oleh para pelaku usaha. Walapun prinsip tersebut telah dinormakan dalam bentuk produk hukum, namun dalam praktik perdagangan hal-hal yang bertolak belakang masih sering dijumpai dalam masyarakat. Di dalam praktek pun, adagium yang menyatakan bahwa konsumen selaku pembeli harus hati-hati (caveat emptor) masihlah sangat relevan. Banyak kendala-kendala yang dihadapi dalam mewujudkan prinsip tersebut agar dapat diterapkan secara adil dan tepat. Tidak terlaksananya prinsip ini juga tidak hanya dapat dibebankan kepada in bad faith (itikad buruk) dari para pelaku usaha saja, tapi juga dari para konsumen. Banyak konsumen yang enggan atau justru takut untuk melaporkan tindakan para pelaku usaha terhadap kerugian yang dialami terhadap barang-barang yang mereka beli dari pelaku usaha. Jangan berpikir untuk membebankan para pelaku usaha untuk melakukan ganti kerugian, untuk melanjutkan ke jalur persidangan pun tidak.

Efektifitas implementasi prinsip tanggung jawab produk masih jauh dari harapan. Hambatannya tidak hanya dilatarbelakangi oleh sudut pandang si pelaku usaha saja tapi juga pola pikir yang berkembang diantara para konsumen. Setidaknya ada dua faktor yang menyebabkan kurang efektifnya prinsip tanggung jawab produk, antara lain: ${ }^{10}$

1. Masih Banyak Konsumen yang Tidak Mengajukan Gugatan atas Tanggung Jawab Produk;

Pada bulan November 2004, peserta ASEAN-China Summit menandatangani Naskah Perjanjian Perdagangan Barang (The Framework Agreement on Trade in Goods) yang berlaku pada 1 Juli 2005. Berdasarkan perjanjian ini negara ASEAN (Indonesia, Thailand, Singapura, Philipina, Malaysia) dan China sepakat untuk menghilangkan 90\% (Sembilan puluh persen) komoditas pada tahun 2010. Untuk negara ASEAN lainnya pemberlakuan kesepakatan dapat ditunda hingga 2015.

${ }^{10}$ Loc. Cit., <http://fh-unsri.info/?p=279>, diakses tanggal 4 Juni 2009. 
2. Kedudukan Pelaku Usaha yang Lebih Kuat Dibandingkan dengan Konsumen.

Penerapan prinsip strict liability di Indonesia sepertinya tidak mudah untuk diterapkan, akan terdapat banyak penolakan-penolakan dari para pelaku usaha menyangkut kelancaran usaha bisnisnya. Kepentingan investasi dan para penanam modal juga harus dipertimbangkan dalam mengkaji kelayakan prinsip strict liability di Indonesia. Disamping kemudahan proses penuntutan ganti rugi juga akan banyak menimbulkan penyalahgunaan proses gugatan hukum yang merugikan para pelaku usaha.

\section{Tanggung Jawab Pelaku Usaha}

Perihal ketentuan yang mengatur tentang tanggung jawab pelaku usaha diatur dalam ketentuan Pasal 19- 8 UUPK. Berdasarkan ketentuan Pasal 19 UUPK tanggung jawab adalah ganti rugi yang dapat berupa pengembalian uang; penggantian barang dan atau jasa; perawatan kesehatan; dan pemberian santunan. Ganti rugi yang dimaksud dalam Pasal 19 UUPK hanya bersifat materiil saja, tidak terkandung kerugian yang bersifat immateriil.

Product Liability secara umum adalah tanggung jawab atas suatu barang atau jasa yang diproduksi oleh perusahaan atau industri dengan prinsip hukum bahwa setiap orang yang melakukan sesuatu yang berakibat merugikan orang lain harus memikul tanggung jawab atas perbuatannya. Inti dari product liability adalah pelaku bertanggung jawab atas kerusakan, kecacatan, penjelasan, ketidaknyamanan dan penderitaan yang dialami oleh konsumen karena pemakaian atau mengkonsumsi barang atau jasa yang dihasilkannya. Product Liability umumnya disebut juga dengan istilah tanggung jawab produk, tanggung gugat produk, atau tanggung jawab produsen. $^{11}$

\footnotetext{
${ }^{11}$ Pengertian lain mengenai Product Liability antara lain oleh NE Algra \& HR HWR Gokkel yaitu tanggung jawab pemilik pabrik untuk barang-barang yang dihasilkan, misalnya yang berhubungan dengan kesehatan pembeli, pemakai (konsumen) atau keamanan produk. Menurut Agnes M. Toar, Product Liability adalah tanggung jawab produsen untuk produk yang dibawanya ke dalam peredaran yang menimbulkan kerugian karena cacat yang melekat pada produk tersebut. Sedangkan Endang Saefullah mendefinisikan Product Liability sebagai suatu tanggung jawab secara hukum dari orang atau badan yang menghasilkan suatu produk (producer, manufacture) atau dari orang atau badan yang menghasilkan (processer, assembler) atau dari orang atau badan yang menjual atau mendistribusikan (seller, distributor) produk tersebut.
} 
Pihak-pihak yang bertanggung jawab dalam pelaksanaan product liability adalah pengusaha dari barang atau produk akhir atau bagian komponen; pengusaha dari barang-barang alam (natural product); supplier dari suatu barang; dan orangorang lain, termasuk pengusaha bengkel dan pergudangan di dalam jaringan penyediaan atau persiapan atau distribusi suatu barang.

\section{Prinsip Hukum Hubungan Pertanggungjawaban}

Prinsip hukum yang dianut dalam hubungan pertanggung jawaban adalah karena adanya kesalahan (tort liability) artinya berdasarkan kesalahan tertentu seseorang dapat menuntut kerugian yang dialaminya dan kesalahan itu ada jika bisa dibuktikan. Doktrin-doktrin mengenai subjek yang melakukan kesalahan pada dasarnya ada empat yaitu caveat emptor, caveat venditor, contractual liability, dan tort liability.

Pada doktrin caveat emptor, konsumen dan pelaku usaha mempunyai kedudukan yang sama dalam melakukan transaksi dimana konsumen tidak perlu dilindungi. Oleh karena itu konsumen harus lebih berhati-hati dan perlu mendapatkan informasi dari pelaku usaha. Jika terjadi kerugian maka itu merupakan kesalahan konsumen. Dimana konsumen yang harus membuktikan adanya kerugian tersebut. Kelemahan teori ini adalah pelaku usaha lebih mengetahui keadaan dan sifat suatu produk. Selain itu juga secara ekonomi kedudukan pelaku usaha lebih tinggi dibandingkan konsumen sehingga posisi konsumen sangat lemah.

Kebalikan dari teori caveat emptor adalah caveat venditor dimana pelaku usaha yang berkewajiban untuk berhati-hati dalam memproses dan memasarkan produknya. Jika konsumen hendak menuntut haknya atas perbuatan pelaku usaha yang merugikan dirinya, konsumen hanya terbatas untuk membuktikan adanya suatu negligence yaitu ketidak hati-hatian pada pihak pelaku usaha sehingga menimbulkan kerugian bagi dirinya. Namun dalam pelaksanaannya, membuktikan negligence sangat sulit bagi konsumen karena yang lebih mengetahui proses produksi adalah pelaku usaha.

UUPK menganut caveat venditor, yaitu sebagaimana terlihat dalam ketentuan:

1) Pasal 19 mengenai produk;

2) Pasal 20 mengenai iklan;

3) Pasal 21 mengenai importir; dan

4) Pasal 24 mengenai penjual kepada penjual lainnya. 
Contractual liability didasarkan pada perjanjian dimana pelaku usaha diminta untuk bertanggung jawab. Kelemahan teori ini adalah menutup kemungkinan bagi gugatan liability jika tidak ada diperjanjian. Selain itu bentuk dan standar perjanjian biasanya dibuat secara sepihak oleh pelaku usaha dengan klausula baku. UUPK menganut teori ini yaitu pada Pasal 26 tapi terbatas dalam bidang perdagangan jasa.

Tort liability Pelaku usaha harus bertanggung jawab terhadap setiap kesalahan yang dilakukannya. Tanggung jawab baru timbul jika pelaku usaha terbukti melakukan kesalahan. Kelemahan teori ini: untuk dapat meminta pertanggungjawaban, konsumen harus lebih dulu membuktikan adanya suatu kesalahan dari pelaku usaha. Prinsip ini dikenal dalam Pasal 1365 KUHPerdata yang dikenal dengan perbuatan melawan hukum (onrechtmatige daad). Pasal 1365 KUHPerdata: tiap perbuatan melanggar hukum yang membawa kerugian kepada seorang lain, mewajibkan orang yang karena salahnya menerbitkan kerugian itu mengganti kerugian tersebut. Pasal 28 UUPK: pembuktian terhadap adanya unsur kesalahan dalam gugatan ganti rugi merupakan beban tanggung jawab pelaku usaha (pembuktian terbalik).

\section{Prinsip Pertanggungjawaban}

Prinsip pertanggungjawaban secara umum ada empat yaitu tanggung jawab karena kesalahan, praduga bertanggung jawab, praduga tidak selalu bertanggung jawab, dan tanggung jawab langsung. Tanggung jawab karena kesalahan (liability based on fault) adalah tanggung jawab yang dianut dalam hukum pidana dan perdata.

Tanggung jawab karena kesalahan (liability based on fault) adalah suatu bentuk tanggung jawab yang dianut dalam Hukum Pidana dan Perdata. Praduga bertanggung jawab (presumption of liability) atau biasa disebut juga sebagai pembuktian terbalik adalah seseorang dianggap bertanggung jawab sampai ia dapat membuktikan bahwa dirinya tidak bersalah.

Sedangkan praduga tidak selalu bertanggung jawab (presumption of non liability) merupakan kebalikan dari prinsip praduga untuk selalu bertanggung jawab, dimana tidak selalu pelaku usaha yang bertanggung jawab. Tanggung jawab mutlak (strict liability) menyatakan bahwa pelaku usaha harus bertanggung jawab atas kerugian konsumen tanpa harus membuktikan ada tidaknya kesalahan pada dirinya. 


\section{Prinsip Tanggungjawab Produk (Product Liability)}

Tanggung jawab produk merupakan suatu istilah terjemahan dari istilah asing "Product(s) Liability" (Inggris) dan istilah "Product Aansprakelijkheid" (Belanda). Ada pula yang menterjemahkannya menjadi "tanggung jawab produsẹn" dari istilah Jerman "Produzenten haftung". Tanggung jawab produk adalah kata dari bahasa Indonesia yang sudah umum dipakai oleh masyarakat umum dan sarjana-sarjana hukum secara teoretis dan praktisi untuk pengertian "responsibility" maupun pengertian "Liability". ${ }^{12}$

Prof. Gautama dalam konvensi di Den Haag tahun 1972 juga membicarakan tentang tanggung jawab produk, namun pada konvensi tersebut belian tidak memberikan terjemahan atau istilah untuk hal tersebut. Secara bergantian dipakai istilah "Product Liability" dan "tanggung jawab untuk hasil produksi" juga "tanggung jawab produsen terhadap hasil produksinya". 13

Secara umum tanggung jawab produk-produk ialah tanggung jawab produsen untuk produk yang telah dibawanya ke dalam peredaran yang menimbulkan atau mengakibatkan kerugian karena cacat yang melekat pada produk tersebut. Selanjutnya dari definisi tersebut dapat dijabarkan lagi bahwa tanggung jawab yang dimaksud disini meliputi tanggung jawab kontraktuil atau berdasarkan perjanjian dan tanggung jawab perundang-undangan berdasarkan perbuatan melanggar hukum. Pengertian produsen dari definisi tersebut adalah produsen (pembuat), grosir (wholesaler), leveransir dan pengecer (retailer) profesional. Produk disini meliputi benda bergerak maupun tidak bergerak yang telah dibawa produsen ke dalam peredaran, maksudnya yang telah ada dalam perdagangan karena tindakan produsen. Kerugian yang dimaksud dengan definisi di atas adalah kerugian yang ditimbulkan atau disebabkan oleh produk dan kerusakan atau musnahnya produk. Sedang pengertian cacat yang melekat pada produk adalah kekurangan pada produk yang menjadi penyebab timbulnya kerugian.

\footnotetext{
${ }^{12}$ Ada sarjana yang mengusulkan untuk mengunakan istilah tanggung gugat untuk pengertian "Liability" dan istilah tanggung jawab hanya dipakai untuk pengertian "Responsibility". Pendapat yang demikian dipengaruhi oleh ajaran belanda dan Inggris yang mempunyai dua istilah untuk pengertian responsibility dan liability. Lain dengan di Perancis yang hanya mengenal satu istilah untuk kedua pengertian tersebut.

${ }^{13}$ S. Gautama, "Kapita Selekta Hukum Perdata Internasional", (tanpa kota, tanpa penerbit dan tanpa tahun), hal. 105.
} 
Ada perbedaan pengaturan tanggung jawab produk di beberapa negara. Di negara-negara kodifikasi biasanya pengaturan tanggung jawab produk merupakan bagian daripada hukum perikatan khususnya hukum perbuatan melanggar hukum. Ada negara yang menempatkan pengaturan daripada tanggung jawab produk dalam hukum konsumen atau hukum perlindungan konsumen. Dan ada pula yang mengusulkan pengaturan tanggung jawab produk dalam hukum kecelakaan atau musibah. Sedangkan pandangan yang paling progresif melihat pengaturan tanggung jawab produk sebaiknya diatur dalam hukum yang tersendiri, yakni "Product Liability Law". Dari berbagai perbedaan pengaturan tersebut dapat disimpulkan hukum tanggung jawab produk merupakan fenomena yang baru menarik perhatian sehingga belum jelas pengaturannya, namun pada umumnya tanggung jawab produk bermula dari hukum perikatan.

Di Indonesia sebagaimana dengan negara kodifikasi hukum tanggung jawab produk merupakan bagian dari hukum perikatan. Selain dari pengaturan tersebut hukum tanggung produk di Indonesia juga sudah banyak diatur dalam bentuk undang-undang maupun peraturan lainnya yang bertujuan melindungi konsumen, namun kontrol penaatan peraturan-peraturan tersebut masih sangat kurang, sehingga peraturan-peraturan tersebut menjadi kurang berfungsi. Masalah tersebut terjadi karena Indonesia merupakan negara yang baru memasuki era industrialisasi. Sikap pemerintah yang demikian lebih melindungi industri sebagai bagian dari kebijaksanaan ekonomi. ${ }^{14}$

\section{Subjek Hukum Tanggung Jawab Produk}

Sebagaimana kita bahas sebelumnya tanggung jawab dari sudut hukum perikatan mempunyai aspek hukum perjanjian dan aspek hukum perbuatan melanggar hukum. Jika ditinjau masalah perjanjian dalam kaitannya dengan

${ }^{14}$ Secara historis di Indonesia (sebelum berlakunya UUPK) pengaturan tentang tanggung jawab secara umum diatur dalam hukum perikatan baik karena persetujuan maupun karena undangundang. Pengaturan tanggung jawab produk dalam hukum perikatan karena persetujuan atau kontraktuil diatur dalam pasal 1243 KUHPerdata dan seterusnya. Penerapkan daripada pasal-pasal tersebut dalam kasus-kasus tanggung jawab produk tidak menimbulkan masalah, cukup dibuktikan adanya wanprestasi daripada salah satu pihak yang ikut dalam perjanjian. Namun dalam hal tidak adanya persetujuan dan suatu produk telah membawa kerugian dalam peredaran maka pasal-pasal wanprestasi dalam KUHPerdata tersebut tidak dapat diterapkan. Untuk hal lnl pasal 1365 KUHPerdata yang merupakan pengaturan umum daripada hukum perbuatan hukum yang akan diterapkan. 
tanggung jawab dalam bidang produksi. Maka dilihat apakah seorang yang memproduksi suatu barang atau kebutuhan tertentu secara lansung atau tidak langsung mempunyai hubungan hukum yang lahir dari kata sepakat dengan pihak tertentu dalam memasarkan produksi. Oleh sebab itu pertama-tama akan ditinjau adalah subjek hukum atau pihak yang terdapat dalam perjanjian yang demikiạn.

Seorang yang akan memproduksi suatu barang senantiasa terikat pada peraturan-peraturan yang dibuat oleh pemerintah dalam kaitannya dengan berbagai macam produksi atau kebutuhan dalam masyarakat. Misalnya seorang akan memproduksi makanan kaleng tertentu, maka paling tidak ia terikat dengan peraturan yang dibuat oleh Departemen perindustrian juga Departemen Kesehatan q.q. Dirjen Pengawasan Obat \& Makanan. Demikian juga halnya dalam produksi berbagai kebutuhan lainnya. Maka kegiatan produksi senantiasa terkait dengan berbagai peraturan yang ditetapkan oleh pemerintah guna mengawasi' serta menjalankan kebijaksanaan pemenuhan kebutuhan barang dao produksi di Indonesia. Dengan demikian dapat ditetapkan bahwa salah satu pihak yang senantiasa ada dalam rangka pengawasan serta pemberian izin produksi tersebut adalah pemerintah lewat berbagai instansi pemerintah. Dengan perkataan lain salah satu pihak dalam hubungan hukum tersebut adalah pemerintah. ${ }^{15}$

Jika masalah tanggung jawab dilihat dari pola hukum perbuatan melanggar hukum, maka subjek hukum tanggung jawab produk juga sama dengan subjek

${ }^{15}$ Hubungan hukum yang terdapat dalam kegiatan produksi dapat disebut sebagai hubungan hukum penetapan syarat secara sepihak oleh pemerintah, sebagai lembaga pengawasan dalam menjalankan kebijaksanaan serta perlindungan masyarakat luas, berkenan dengan kegiatan produksi tertentu. Dalam arti pemerintah secara sepihak menetapkan kebijaksanaan yang telah digariskannya, menetapkan kriteria atau syarat-syarat apa saja yang harus dipenuhi oleh seorang guna dapat melaksanakan produksinya. Kesepakan antara para pihak diwujudkan dalam pemberian izin berproduksi oleh pemerintah terhadap pemohon. Izin doiberikan berdasarkan kehendak dan kemauan pihak pemohon yang dinyatakan kepada pemerintah untuk mentaati ketentuan yang telah dibuatoleh pemerintah tersebut. Misalnya pemerintah lewat DepartemenKesehatan menetapkan peraturan Menteri Kesehatan Republik Indonesia No.359/Men/Kes/PerIX/1983 tentang bahan kosmetika dan zat pewarna. Dalam peraturan tersebut tertuang keinginan pemerintah demi kepentingan masyarakat. Jika ditaati oleh pemohon produksi kegiatan kosmetika dan zat pewarna, maka pemohon tersebut mengikat diri menjadi salah satu pihak. Dengan kata lain para pihak sepakat untuk memberlakukan peraturan tersebut sebagai hukum memaksa yang harus ditaati. Dan pelanggaran terhadapnya dengan demikian juga berarti pelangggaran atau pengingkaran akan kesepakatan para pihak tersebut. 
perbuatan melanggar hukum yaitu terdiri dari manusia perorangan, badan hukum dan juga penguasa.

Secara global kita mengetahui dalam kenyataanya terdapat tiga unsur subjek hukum yang selalu terlibat dalam usaha lancar tidaknya suatu arus produksi. ketiga unsur tersebut adalah:

1) Pemerintah;

2) produsen;

3) konsumen dalam arti luas.

Pemerintah mempunyai kepentingan yang besar sebagai penengah hubungan antara produsen dan konsumen. Sebagai penengah hubungan dan merupakan badan hukum publik, maka kepentingan yang dijalankan adalah kepentingan pengawasan serta perlindungan kedua pihak. Tindakan satu pihak misalnya produsen tidak boleh terlalu merugikan konsumen.

Dalam bidang tanggung jawab produk maka kepentingan antara produsen dan konsumen haruslah seimbang. Dan pemerintah sebagai fungsi pertama diatas menjadi wasit pengawas yang bijaksana. Bilamana dalam keseimbangan tersebut terjadi kegoncangan maka ketiga unsur subjek hukum tersebut dapat dituntut berdasarkan hukum perbuatan melanggar hukum.

Dengan demikian subjek hukum dalam hukum tanggungjawab berdasarkan perbuatan melanggar hukum adalah manusia perorangan, badan hukum yang merupakan produsen maupun konsumen dan Pemerintah yang merupakan badan pengawas.

Kenyataan dewasa ini menunjuk bahwa produk yang dihasilkan dan dipasarkan produsen pada umumnya tidak lansung sampai di tangan konsumen selaku pemakai akhir dari produk tersebut, lazimnya produsen mengunakan para perantara untuk menyalurkan hasil produksinya antara lain:

1) Perantara perdagangan (merchant, middleman seperti wholesaler [pedagang besar], retailer [pedagang kecil]).

2) Perantara agen (Agent-middleman seperti broker, manufacturer agent, selling agent dan sebagainya).

\section{Macam-macam Tanggung Jawab Produk Menurut KUH Perdata}

Tanggung jawab produk dari sudut hukum perikatan, buku III KUHPerdata terdiri dari dua macam antara sebagai berikut: 
a) Tanggung jawab produk secara Kontraktual

Tanggung jawab produk secara kontraktual tunduk pada hukum perjanjian pada umumnya. Disini diberlakukan pasal 1313 KUHPerdata sampai pasal 1351 KUHPerdata. Ketentuan mengenai syarat-syarat sahnya suatu persetujuan dalam pasal 1320 KUHPerdata harus ada. Dan persetujuan yang telah dibuat secara sah berdasarkan pasal 1320 KUHperdata adalah mengikat sebagai undang-undang bagi para pihak (pasal 1338 KUHPerdata).

Bilamana salah satu pihak dalam perjanjian tidak melaksanakan atau lalai melaksanakan perikatan maka ia dikatakan melakukan wanprestasi. Dalam hal demikian ketentuan tentang wanprestasi dalam pasal 1243 KUPerdata dan seterusnya berlaku baginya.

b) Tanggung jawab produk secara deliktual

Jikalau kita membatasi tanggung jawab deliktual dan mengabaikan tanggung jawab kontraktual, maka akan kita jumpai pasal 1365 KUHPerdata, yang menggugat produsen untuk kerugian yang terjadi sebagai akibat masuknya produk yang cacat dalam masyarakat. Disini harus dibuktikan produsen telah melakukan tindakan melanggar hukum, yang merupakan tanggung jawabnya. Yang menderita kerugian harus membuktikan kesalahan produsen. Dengan demikian biasanya penggugat biasanya dibebani dengan pembuktian yang sangat berat, karena harus membuktikan semua unsur-unsur yang terdapat dalam pasal 1365 KUHPerdata yang merupakan pengaturan umum hukum perbuatan melanggar hukum.

\section{Prinsip Tanggung Jawab Mutlak (Strict Liability)}

Penggunaan prinsip strict liability ditujukan agar produsen benar-benar bertanggung jawab terhadap kepentingan konsumen. Prinsip strict liability diterapkan karena seharusnya yang menanggung beban kerugian antara konsumen sebagai korban dan pelaku usaha adalah pihak yang memproduksi barang dan jasa yang cacat atau berbahaya. Dengan mengedarkan atau menempatkan barang-barang di pasar, hal ini berarti pelaku usaha telah menjamin bahwa barang-barang tersebut aman untuk dikonsumsi atau digunakan. Selain itu penerapan prinsip strict liability dapat menghilangkan proses yang panjang dalam penuntutan. Secara ilmiah dan teknis pada saat produk tersebut diedarkan tidak mungkin terjadi cacat. Bila pihak yang menderita kerugian atau pihak ketiga turut menyebabkan terjadinya kerugian tersebut. Kerugian terjadi akibat keadaan memaksa. 
Alasan-alasan mengapa prinsip tanggung jawab mutlak (strict liability) yang diterapkan dalam hukum tentang product liability adalah:

1. di antara korban/konsumen di satu pihak dan produsen di lain pihak, beban kerugian (resiko) seharusnya ditanggung oleh pihak yang memproduksi/ mengeluarkan barang-barang cacat/berbahaya tersebut di pasaran;

2. dengan menempatkan/mengedarkan barang-barang di pasaran, berarti produsen menjamin bahwa barang-barang tersebut aman dan pantas untuk dipergunakan, dan bilamana terbukti tidak demikian, pelaku usaha harus bertanggung jawab;

3. sebenarnya tanpa menerapkan prinsip tanggung jawab mutlakpun produsen yang melakukan kesalahan tersebut dapat dituntut melalui proses penuntutan beruntun, yaitu konsumen kepada pedagang eceran, pengecer kepada grosir, grosir kepada distributor, distributor kepada agen, dan agen kepada produsen. Penerapan strict liability dimaksudkan untuk menghilangkan proses yang panjang ini.

Selain hal tersebut diatas, ada alasan-alasan lain yang memperkuat penerapan prinsip strict liability tersebut yang didasarkan pada prinsip Social Climate Theory:

1. Manufacturer adalah pihak yang berada dalam posisi keuangan yang lebih baik untuk menanggung beban kerugian, dan pada setiap kasus yang mengharuskannya mengganti kerugian pengusaha akan meneruskan kerugian tersebut dan membagi resikonya kepada banyak pihak dengan cara menutup asuransi yang preminya dimasukkan ke dalam perhitungan harga dari barang hasil produksinya, hal ini dikenal dengan deep pockets theory.

2. Terdapatnya kesulitan dalam membuktikan adanya unsur kesalahan dalam suatu proses manufacturing yang demikian kompleks pada perusahaan besar (industri) bagi seorang konsumen/korban/penggugat secara individual.

Meskipun sistem tanggung jawab pada product liability berlaku prinsip strict liability, pihak produsen dapat membebaskan diri dari tanggung jawabnya, baik untuk seluruhnya atau untuk sebagian. Hal-hal yang dapat membebaskan tanggung jawab produsen tersebut adalah:

1. Jika produsen tidak mengedarkan produknya (put into circulation);

2. Cacat yang menyebabkan kerugian tersebut tidak ada pada saat produk diedarkan oleh produsen, atau terjadinya cacat tersebut baru timbul kemudian; 
3. Bahwa produk tersebut tidak dibuat oleh produsen baik untuk dijual atau diedarkan untuk tujuan ekonomis maupun dibuat atau diedarkan dalam rangka bisnis;

4. Bahwa terjadinya cacat pada produk tersebut akibat keharusan memenuhi kewajiban yang ditentukan dalam peraturan yang dikeluarkan oleh pemerintah;

5. Bahwa secara ilmiah dan teknis (state of scientific an technical knowledge, state or art defense) pada saat produk tersebut diedarkan tidak mungkin cacat;

6. Bila terkait dengan produsen dari suatu komponen, bahwa cacat tersebut disebabkan oleh desain dari produk itu sendiri dimana komponen telah dicocokkan atau disebabkan kesalahan pada petunjuk yang diberikan oleh pihak produsen tersebut;

7. Bila pihak yang menderita kerugian atau pihak ketiga turut menyebabkan terjadinya kerugian tersebut (contributory negligence);

8. Kerugian yang terjadi diakibatkan oleh Acts of God atau force majeur.

Dengan diberlakukannya prinsip strict liability diharapkan para produsen dan industriawan di Indonesia menyadari betapa pentingnya menjaga kualitas produkproduk yang dihasilkannya, sebab bila tidak, selain akan merugikan konsumen juga akan sangat besar risiko yang harus ditanggungnya. Para produsen akan lebih berhati-hati dalam memproduksi barangnya sebelum dilempar ke pasaran sehingga konsumen, baik dalam maupun luar negeri tidak akan ragu-ragu membeli produksi Indonesia.

Tanggung jawab mutlak (strict liability) adalah bentuk khusus dari tort (perbuatan melawan hukum), yaitu prinsip pertanggung jawaban dalam perbuatan melawan hukum yang tidak didasarkan kepada kesalahan. tetapi prinsip ini mewajibkan pelaku langsung bertanggung jawab atas kerugian yang timbul karena perbuatan melawan hukum itu. Karenanya, prinsip strick liability ini disebut juga dengan liability without fault.

Di Indonesia konsep strict liability (tanggung gugat mutlak, tanggung jawab resiko) secara implisit dapat di temukan dalam pasal 1367 dan pasal $1368 \mathrm{KUH}$ Perdata. Pasal $1367 \mathrm{KUH}$ Perdata mengatur tentang tanggung jawab seseorang atas kerugian yang disebabkan oleh barang-barang yang ada di bawah pengawasannya. Misalnya seorang pemilik barang tertentu, suatu ketika barang itu mengakibatkan kerugian bagi orang lain, misalnya meledak dan melukai orang lain, maka pemiliknya bertanggung jawab atas luka-luka yang ditimbulkan, tanpa mempersoalkan ada tidaknya kesalahan yang menimbulkan ledakan itu. Menerapkan 
pasal 1367 KUH Perdata seperti ini memang membutuhkan penafsiran yang cukup berani, tetapi sudah dapat dijadikan sebagai salah satu dasarnya. Kata-kata yang berada di bawah pengawasannya pada pasal 1367 KUH Perdata itu dapat dipandang sebabai faktor yang berdiri sendiri sebagai penyebab timbulnya kerugian, yang berarti tidak membutuhkan adanya kesalahan pemilik barang. ${ }^{16}$

Dalam UUPK dasar hukum yang dipakai oleh konsumen untuk mempertahankan haknya yaitu dengan menuntut ganti kerugian atas dasar pasal 4 dan 5 mengenai hak dan kewajiban konsumen. Kemudian pada pasal 6 sampai dengan pasal 13 mengenai hak dan kewajiban pelaku usaha serta perbuatan yang dilarang bagi pelaku usaha. Sedangkan pasal yang khusus mengenai tanggung jawab pelaku usaha/produsen terdapat pada pasal 19, 23, 24, 25, 27 dan 28 UUPK. Pelaku usaha bertanggung jawab memberikan ganti rugi atas kerusakan, pencemaran, dan/atau kerugian konsumen akibat mengkonsumsi barang dan/atau jasa yang dihasilkan atau diperdagangkan.

Pada pasal 19 menjelaskan tentang tanggung jawab produsen (pelaku usaha) yang merupakan tanggung jawab berdasarkan kesalahan, sesuai dengan pasal 1365 KUHPerdata, hanya saja sepanjang pelaku usaha benar-benar bersalah, dan memenuhi unsur-unsur dalam pasal tersebut. Namun jika produsen dapat membuktikan bahwa kesalahan bukan pada pihaknya tetapi pada pihak konsumen, maka resiko di tanggung sendiri oleh konsumen.

16 Dengan mempergunakan konsep strict liability pada bidang perlindungan konsumen, khususnya tanggung jawab produk, akan memudahkan pembuktian, yang pada akhirnya benar-benar memberikan perlindungan kepada konsumen. Ini tidak dimaksudkan untuk menempatkan produsen pada posisi yang sulit semata-mata, tetapi karena kedudukan produsen yang jauh lebih kuat dibandingkan konsumen. Antara lain disebabkan kemampuan pengusaha di bidang keuangan, kemajuan teknologi industri yang amat pesat, dan kemampuan pengusaha untuk memakai ahli hukum yang terbaik dalam menghadapi suatu perkara (Koesnadi Hardjasoemantri, 1992). Alasan lain yang dapat dijadikan dasar untuk memberlakukan atau memakai konsep strict liability dalam perlindungan konsumen, khususnya tanggung jawab produk adalah dengan melihat pada tujuan dari perlindungan itu sendiri. Kata perlindungan mengandung arti memberi kemudahan bagi konsumen untuk mempertahankan dan atau memperoleh apa yang menjadi haknya. Menurut Shidarta, dengan memberlakukan konsep pertanggungjawaban mutlak, maka apa yang diharapkan dari perlindungan konsumen dapat tercapai sebab pihak konsumen yang akan dilindungi itu akan dapat dengan mudah mempertahankan atau memperoleh haknya jika dibandingkan dengan konsep kesalahan, dimana konsumen masih di bebani kewajiban untuk membuktikan kesalahan produsen. 


\section{Penerapan Prinsip Tanggung Jawab Mutlak (Strict Liability) Di Belanda Dalam Konteks Perbandingan Dengan Negara Yang Telah Menerapkan Prinsip Dimaksud}

Menunjuk pada studi banding tersebut, maka secara umum dapat disampaikan kondisi faktual di lapangan dan informasi data yang diperoleh. Hasil kunjungan adalah sebagai berikut:

\section{Hasil Riset pada Kamer Van Koophandel di Maastricht}

Berdasarkan pertemuan dengan Joseph W. Chung dari Kamer Van Koophandel Belanda atau Chamber of Commerce \& Industry Limburg di Maastricht Belanda diperoleh keterangan yang secara tidak langsung mengarah pada penerapan prinsip strict liability meskipun lebih banyak substansinya dalam lingkup product liability, yaitu:

1) tingkat kesadaran hukum masyarakatnya relatif tinggi, maka terhadap praktek jual beli lazimnya yang terjadi apabila ternyata produk yang dibeli tidak berfungsi ataupun tidak sebagaimana mestinya, pembeli dapat kembali kepada penjual dan meminta ganti atas produk yang gagal berfungsi tersebut. Artinya, penjual apabila pembeli dapat memberikan bukti-bukti bahwa barang tersebut dibeli dari tokonya, maka pemilik toko berkewajiban untuk mengganti barang atau mengembalikan uang senilai dengan harga barang yang dibelinya.

2) Jenis produk/barang juga sangat menentukan, yaitu apabila terhadap produk-produk makanan dan minuman gugatan terhadap perlindungan hukumnya terhadap konsumen lebih tinggi. Hal mana disebabkan produk-produk tersebut dikonsumsi dan merupakan asupan bagi manusia. Sehingga ketentuan-ketentuan mendasar seperti pencantuman informasi tentang komposisi/kandungan bahan makanan dan minuman yang terkandung didalamnya haruslah jelas. Kejelasan informasi atas komposisi/kandungan tersebut tidak semata-mata memuat tentang kandungan dari makanan dan minuman itu sendiri, tetapi justru memberikan informasi terhadap konsumen yang tidak dapat mengonsumsi ataupun memiliki pantangan-pantangan untuk mengonsumsi makanan dan minuman tersebut.

3) Selain daripada itu pencantuman informasi maupun isi kontrak jual beli haruslah jelas dan mudah dibaca, sehingga konsumen dalam hal ini dianggap telah dapat membaca. 
4) Sehubungan produk-produk, baik yang merupakan produk lokal maupun produk luar negeri, ditentukan bahwa semua produk yang dikirim harus sesuai dengan informasi yang dinyatakan dan tertera, misalnya berat, kualitas dan lain sebagainya adalah benar dan tidak menipu. Konsumen tidak boleh menilai ataupun beranggapan bahwa dirinya dipermainkan atau bahkan tertipu.

5) Belanda sebagai salah satu anggota dari masyarakat Uni Eropa berupaya semaksimal mungkin agar tidak terjadi sengketa maupun perselisihan terhadap produk-produk/barang-barang yang diperjualbelikan dilingkungan negara-negara anggota Uni Eropa. Oleh karenanya masing-masing anggota Uni Eropa senantiasa ketat dalam memperhatikan dan mencantumkan harga, kualitas dan standarisasi produk.

6) Apabila terjadi permasalahan terhadap produk/barang tertentu maka prosesnya untuk kali pertama diselesaikan antar penjual dengan pembeli. Penggunaan jasa pengacara yang ahli dibidang perlindungan konsumen merupakan dan penyelesaian perkara di pengadilan merupakan opsi terakhir yang dipergunakan ataupun tingkat kompleksitas permasalahan yang dihadapi yang membutuhkan adanya ahli hukum yang sangat paham mengenai substansi perkara.

7) Upaya untuk memecahkan masalah perlindungan konsumen tersebut dimungkinkan untuk dilakukannya pemeriksaan terhadap material barang, penyelidikan maupun penyidikan terhadap kejelasan standar produk/barang, siapakah pihak yang harus bertanggung jawab atas produk/barang, melibatkan para ahli bidang perlindungan konsumen dan ahli terhadap produk, dapat melibatkan biro yang memeriksa standar kualitas produk/barang.

8) Terhadap korban dibenarkan untuk menuntut pihak supplier untuk mengganti rugi pihaknya, bahkan terbuka peluang untuk melakukan proses penuntutan secara hukum terhadapnya.

9) Namun, bagaimana halnya konsumen mengetahui informasi tentang perlindungan konsumen dan hak-haknya atas setiap produk yang dibeli dan dipergunakannya. Di Belanda terdapat proses edukasi bagi masyarakat terhadap bidang perlindungan konsumen, baik yang dilakukan melalui siaran televisi, siaran radio atau bahwa dilakukan oleh institusi-institusi yang berkecimpung dibidang perlindungan konsumen. 


\section{Hasil Riset pada Consumenten Bond di Den Haag}

Berdasarkan pertemuan dengan Consumenten Bond di Den Haag yang dalam hal ini diwakili oleh Michiel Karsken dan Bregje Krijnen, secara umum diperoleh keterangan sebagai berikut:

1) Consumenten Bond adalah lembaga perlindungan konsumen yang berbentuk yayasan dan bersifat sebagai badan hukum nirlaba yang bertujuan untuk memberikan perlindungan dan menjadi wakil dari konsumen dalam menghadapi perkara-perkara konsumen.

2) Belanda tidak menggunakan prinsip strict liability tetapi dalam realitasnya memberlakukan prinsip product liability yang lebih diperketat pemberlakuannya.

3) Sejalan dengan pendapat yang dikemukakan oleh Kamer van Koophandel dalam penyelesaian perselisihan disampaikan upaya penyelesaian perselisihan konsumen, dimana informasi yang kami terima adalah upaya penyelesaian sengketa konsumen dilakukan oleh dan antara konsumen dengan produsen terlebih dahulu, apabila terkendala maka melibatkan lembaga perlindungan konsumen dan jalan terakhir adalah dengan menempuh proses peradilan.

4) Dalam lingkup perlindungan konsumen struktur hukum yang diberlakukan adalah dalam tatanan contract law yang lebih ditekankan pada consumer contract dan public law.

5) Dalam penerapan sanksi atas produk yang merugikan konsumen dipergunakan tanggungjawab berdasarkan prinsip mata rantai, artinya tidak selalu produsen yang dipersalahkan tetapi dalam hal ini dilihat kerusakan barang terjadi tahapan mana. Artinya barang dapat saja rusak pada saat barang tersebut ada ditangan distributor dan bukan dikarenakan kesalahan produser.

6) Perihal lingkup hukum perlindungan konsumen yang pengaturannya dalam:

a. tatanan contract law dikarenakan basis utamanya adalah hukum perdata, dimana dalam hal perikatan dikarenakan timbulnya hak dan kewajiban dikarenakan hubungan kontraktual dimaksud.

b. tatanan consumer sales dikarenakan Belanda mengacu pada standar peraturan perlindungan konsumen yang berlaku di masyarakat Uni Eropa.

c. tatanan hukum publik dikarenakan produk-produk/barang-barang tersebut dipergunakan secara massal oleh masyarakat. Implikasi 
terhadap dampaknya pun terbuka kemungkinan dirasakan oleh banyak orang.

Oleh karenanya di Belanda turut diatur mengenai hukum tentang makanan (food law), yang dikeluarkan oleh dinas yang berwenang, khususnya terhadap consumer goods product. Dinas dimaksud tidak hanya berwenang terhadap lingkup pertanggungjawaban atas produk/ barang tetapi lebih kepada praktek perdagangan yang wajar, termasuk didalamnya bidang periklanan, yang juga dianggap memiliki tanggung jawab tentang bagaimana mereka memperkenalkan produk tersebut kepada masyarakat.

7) Menunjuk pada ketentuan hukum perdata Belanda diatur bahwa produsen bertanggung jawab atas kerusakan barang. Meskipun demikian di dalam hukum perdata Belanda tetap terdapat pengecualian-pengecualian terhadap tanggung jawab tersebut di atas. Apabila ternyata produsen termasuk dalam kategori yang dikecualikan tersebut, maka pihaknya tidak dapat dipersalahkan.

Perlu untuk disampaikan pula bahwa tanggung jawab dimaksud ditentukan besarannya pastinya. Artinya, penggantirugian diperhitungkan berdasarkan kerugian material dan bukan berdasarkan perhitungan yang bersifat imaterial. Tidaklah dapat seorang konsumen meminta penggantirugian berdasarkan kerugian imaterial karena hal tersebut tidak dapat diperhitungkan secara pasti dan permintaan tersebut dapat mengajukan permohonan ganti rugi yang tidak terbatas. Kondisi ini tidak dibenarkan berdasarkan hukum Belanda.

8) Dasar penghitungan kerugian secara material dapat dengan cara perbandingan, yaitu perhitungan periode seseorang tidak dapat bekerja, memperbandingkan antara keadaan pada saat terjadinya musibah sampai dengan kondisi terkini si korban.

9) Perlindungan konsumen di Belanda dalam hal ini juga menekankan pada perlindungan atas isi perjanjian yang tidak seimbang. Terhadap kondisi isi perjanjian yang tidak seimbang atau merugikan konsumen tersebut harus dapat dibuktikan bahwa memang terdapat penyimpangan. Apabila tidak dapat dibuktikan maka produsen maupun pihak dari rantai distribusi produk/barang tidak dapat dipersalahkan atau bebas dari kesalahan.

10) Ketentuan terhadap informasi produk yang harus sesuai antara kandungan dan informasi yang dinyatakan merupakan suatu 
keharusan yang mengarah sebagai sesuatu hal yang bersifat mutlak. Dengan kata lain tidak ada pengecualian terhadap kondisi tersebut. Terutama hal yang dihindari adalah apabila informasi yang dinyatakan tersebut tidak sesuai dengan faktanya.

11) Consumenten Bond bukan merupakan lembaga yang menyelesaikan perselisihan dalam artian mengambil alih fungsi badan peradilan. Tetapi fungsinya adalah sebagai lembaga alternative dispute resolution. Alasan yang melatarbelakanginya adalah dikarenakan apabila perselisihan perlindungan konsumen ini di bawa ke pengadilan, maka penyelesaiannya akan sangat rumit dan berbelit. Proses beracara di pengadilan di Belanda tidak jauh berbeda dengan di Indonesia, khususnya mengenai jangka waktu proses persidangan yang memakian waktu $1 \mathrm{~s} / \mathrm{d}$ 1,5 tahun untuk menangani perkara hingga selesai. Dengan kata lain Consumenten Bond adalah lembaga yang menyelesaikan perselisihan diluar badan peradilan. Beberapa perkara yang seringkali ditangani oleh lembaga ini adalah permasalahan-permasalahan dibidang perbankan, telekomunikasi, pariwisata dan lain sebagainya.

12) Consumenten Bond lebih memiliki fungsi sebagai mediator ataupun memfasilitasi upaya penyelesaian yang kemudian diikuti dengan penyelesaian secara arbitrase yang bersifat privat. Apabila dalam realitasnya ternyata para pihak yang difasilitasi tidak merasa puas atas hasil yang telah diupayakan oleh Consumenten Bond, maka para pihak dapat mengajukan perkara tersebut ke badan peradilan.

13) Hambatan utama dari penyelesaian perkara di pengadilan adalah berkenaan dengan jangka waktu, biaya pengacara dan lain sebagainya. Perihal kompensasi yang ingin diajukan atas kerugian perlindungan konsumen ini, Pasal 305 Kitab Undang-Undang Hukum Perdata Belanda menegaskan bahwa para pihak yang bersengketa maupun melalui wakil-wakilnya yang ditunjuk dapat mengajukan permasalahan ini ke pengadilan.

14) Consumenten Bond dalam kapasitasnya memiliki otoritas untuk dapat mewakili pihak konsumen tanpa perlu adanya surat kuasa (khusus) dikarenakan lembaga ini telah diberikan otoritas untuk melakukan perbuatan hukum tersebut. Kapasitas ini berkenaan dengan kepentingan dari konsumen yang dirugikan, seperti manakala pedagang menyangkal terhadap tanggung jawabnya, maka hal tersebut dapat segera ditanggapi oleh Consumenten Bond. Pertimbangan lain 
yang menjadi pemikiran tersebut adalah jika seseorang harus berhadapan dengan perusahaan besar, maka dapat dipastikan bahwa orang yang bersangkutan akan mengalami kesulitan yang teramat besar. Oleh karenanya hal tersebut diambil alih Consumenten Bond. Consumenten Bond adalah sebuah institusi publik yang memberikan bantuan kepada masyarakat dibidang perlindungan konsumen dan mengingat bentuknya sebagai sebuah organisasi kemasyarakatan, didalamnya terdapat keanggotaan yang berasal dari para anggota masyarakat di Belanda.

15) Merujuk pada informasi yang disampaikan oleh Consumenten Bond disebutkan bahwa ombudsman di Belanda tidak memiliki otoritas untuk menangani perkara-perkara perlindungan konsumen. Mengingat bahwa kompetensi ombudsman hanya sebatas perkara-perkara yang menyangkut pelayanan publi yang seharusnya diberikan oleh pemerintah kepada masyarakatnya. Dengan kata lain ombudsman tidak dapat menangani perkara-perkara yang berkenaan dengan masalah bisnis, dimana perlindungan konsumen termasuk dalam lingkup privat dikarenakan begitu kuatnya aspek perikatan.

16) Menunjuk pada ketentuan Pasal 185 Kitab Undang-Undang Hukum Perdata Belanda disebutkan, bahwa Produsen tidak bertanggung jawab untuk kerugian yang diakibatkan dari cacatnya suatu barang, ketentuan pasal ini menekankan pada aspek pengecualian tetapi sebenarnya apabila ditelaah secara seksama maka pada hakekatnya tanggung jawab produk tetap merupakan tanggung jawab dari produsen dan bukan pada penjual. Khususnya terhadap hal-hal yang tidak dikecualikan oleh pasal tersebut. Terdapat suatu hal yang menarik adalah di Belanda dan pada umumnya di Eropa perusahaanperusahaan lazimnya menarik produk-produknya yang diduga bermasalah meskipun belum terjadi insiden. Kebijaksanaan semacam ini diambil dikarenakan berdasarkan pada penegakan tanggung jawab produk.

17) Berkenaan dengan penerapan peraturan tanggung jawab produk, maka lingkup pertanggungjawaban atas sesuatu produk/barang tidak melulu harus berada ditangan produsen, tetapi dilihat secara seksama dengan menggunakan penelusuran mata rantai distribusi barang sebelum pada akhirnya sampai ke tangan konsumen. Pembuktian merupakan faktor terpenting untuk menentukan siapakah yang harus bertanggung jawab atas rusak tidak berfungsinya suatu produk/barang. Meskipun 
demikian adalah dipahami manakala penjual eceran tidak dapat dimintakan pertanggung jawabannya secara penuh, yaitu dengan memposisikan penjual eceran tersebut sama seperti produsen. Oleh karenanya titik berat tanggung jawab produksi di Belanda tetap dititikberatkan pada produsen, sepanjang dapat dibuktikan bahwa produsenlah pihak yang seharusnya bertanggung jawab atas terjadinya kerugian tersebut.

18) Belanda dalam hal ini memberlakukan ketentuan tanggung jawab produk dalam lingkup yang sangat detail dan terperinci, sehingga pemikirannya adalah sedapat mungkin permasalahan dapat diselesaikan cukup dengan menegakkan peraturan-peraturan tentang tanggung jawab produk.

19) Manakala prinsip tanggung jawab produk telah berhasil dan efektif diterapkan, maka tidak ada alasan untuk memberlakukan prinsip strict liability. Namun demikian peraturan yang diberlakukan di Belanda sangatlah ketat dan hal ini dijadikan sebagai posisi tawar untuk tidak memberlakukan prinsip strict liability di Belanda, antara lain yaitu harus senantiasa dipastikan bahwa produk-produk yang beredar di pasar Belanda adalah produk-produk yang terjamin keamanannya, dilakukan pengetesan/pengujian terhadap produk-produk yang beredar secara berkelanjutan, proses penyuluhan dan sosialisasi yang berkelanjutan oleh pemerintah dan institusi terkait, dan informasi yang dinyatakan dalam label produk harus dapat terjamin keidentikannya dengan kandungan sebenarnya.

20) Terhadap keadaan semacam ini undang-undang tetap memperhatikan perlindungan bagi para produsen dalam keberimbangan. Seperti halnya jika ada konsumen yang mengajukan gugatan secara umum maka seharusnya dalil yang dipergunakan tidak boleh mempergunakan klausula-klausula yang bersifat spesifik dan pengecualian dalam Pasal 185 tersebut di atas merupakan salah satu hak istimewa yang diberikan oleh undang-undang dari hanya sekedar dipersalahkan oleh para konsumen. 


\section{Hasil Diskusi dengan Prof. Jan van Dalen Guru Besar Maastricth University}

Berdasarkan pertemuan dengan Prof. Jan van Dalen yang dilaksanakan di Kedutaan Besar Republik Indonesia (KBRI) Den Haag, secara umum diperoleh keterangan sebagai berikut:

1) Belanda tidak menggunakan prinsip strict liability tetapi dalam realitasnya memberlakukan prinsip product liability yang lebih diperketat pemberlakuannya.

2) Sejalan dengan pendapat yang dikemukakan oleh Kamer van Koophandel dan Consumenten Bond dalam penyelesaian perselisihan disampaikan upaya penyelesaian perselisihan konsumen, dimana informasi yang kami terima adalah upaya penyelesaian konsumen dilakukan oleh dan antara konsumen dengan produsen terlebih dahulu, apabila terkendala maka melibatkan lembaga perlindungan konsumen dan jalan terakhir adalah dengan menempuh proses peradilan.

3) Dalam lingkup perlindungan konsumen struktur hukum yang diberlakukan adalah dalam tatanan contract law yang lebih ditekankan pada consumer contract dan public law.

4) Dalam penerapan sanksi atas produk yang merugikan konsumen dipergunakan tanggungjawab berdasarkan prinsip mata rantai, artinya tidak selalu produsen yang dipersalahkan tetapi dalam hal ini dilihat kerusakan barang terjadi tahapan mana. Artinya barang dapat saja rusak pada saat barang tersebut ada ditangan distributor dan bukan dikarenakan kesalahan produser.

5) Penggantianrugian terlebih dahulu oleh produsen dalam perkara konsumen dapat diterapkan meskipun Belanda tidak menggunakan prinsip strict liability.

6) Belanda tunduk pada ketentuan umum bidang perlindungan konsumen yang berlaku pada negara-negara Uni Eropa, tetapi hanya Perancis dan Jerman yang secara khusus memberlakukan prinsip strict liability, yang menurutnya pemberlakuan prinsip tersebut lebih dikarenakan adanya faktor budaya.

7) Selanjutnya Prof. Jan van Dalen menekankan bahwa faktor keamanan atas produk merupakan faktor utama yang harus senantiasa diperhatikan. Tujuannya adalah untuk meminimalisir terjadinya kerugian maupun insiden yang akan dialami oleh konsumen di Eropa pada umumnya. Salah satu bidang yang sangat kompleks dalam 
penanganan perlindungan konsumen adalah bidang makanan oleh karenanya terhadap hukum tersendiri yang mengatur perihal makanan. Hukum tentang makanan tersebut terintegrasi erat dengan hukum perlindungan konsumen. ${ }^{17}$

8) Belanda memiliki complaint committee yang bertugas untuk menerima berbagai macam keluhan dari para konsumen. Terutamanya adalah untuk menghadapi itikad baik dari produsen yang agak diragukan. Apabila ternyata terjadi insiden dimana produsen atau pelaku usaha tidak memiliki itikad baik untuk menyelesaikan perkara yang terjadi, maka konsumen dapat mengajukan permasalahan tersebut ke complaint committee.

9) Terbuka kemungkinan dalam kasus perlindungan konsumen terdapat kekosongan hukum dikarenakan sifat khusus dari perkara yang terjadi. Sekiranya terjadi keadaan semacam ini, maka di Belanda, cara yang ditempuh adalah dengan mencari hukum yang mendekati atau relevan untuk dipergunakan yang dinilai sebagai hukum yang paling baik untuk diterapkan dalam perkara dimaksud. Sama halnya seperti hukum di Indonesia dimana hakim dapat menentukan hukum yang berlaku dan hakim tidak dapat menjatuhkan putusan yang menyatakan bahwa belum ada hukum yang mengatur. Keadaan semacam ini apabila tidak secara bijak ditangani akan menjadi suatu bentuk preseden buruk dalam lingkup badan peradilan.

10) Sedikit disinggung kembali mengenai pengungkapan informasi atas suatu produk. Adalah wajib bagi produsen untuk menyatakan bahwa produk tersebut mengandung bahan-bahan yang berbahaya dan membahayakan. Secara spesifik dapat disampaikan bahwa dalam kaitannya dengan hubungan konsumen aspek yang penting untuk selalu diperhatikan dan dianalisis adalah terhadap hal tata cara penggunaan produk yang seharusnya (dari sisi konsumen) dan tata

17 Mengingat sedemikian rumitnya pengaturan tentang hukum makanan, maka aspek makanan ini sangat ketat dalam pengaturan lingkup pertanggungjawabannya. Sehingga lingkup bidang pertanggungjawaban yang dalam hal ini berkenaan dengan perlindungan konsumen sedikit banyak mengadopsi dari segala sesuatu yang telah diatur dalam hukum tentang makanan dimaksud. Makanan di Eropa merupakan satu sektor yang sangat diperhatikan mengingat produk tersebut langsung dikonsumsi oleh manusia dan jika terjadi kesalahan maka dampaknya dapat secara langsung dirasakan oleh orang-orang yang mengonsumsinya. 
cara memproduksi produk/barang yang paling baik (dari sisi produsen).

11) Selain daripada itu hukum mulai dihadapkan dengan tekanan-tekanan ekonomi, teknologi, politik dan berbagai macam hal lainnya. Oleh karenanya di Belanda sedikit banyak sangat sulit untuk tetap mengupayakan perlindungan konsumen secara maksimal dikarenakan banyak faktor yang beberapa waktu belakangan ini memberikan hambatan dalam penegakannya.

12) Satu hal yang menarik perhatian adalah meskipun di Belanda hanya memberlakukan ketentuan tentang tanggung jawab produk, tetapi berdasarkan pernyataan Prof. Jan van Dallen disebutkan, bahwa konsumen tetap dapat memperoleh ganti rugi dari produsen/pelaku usaha tanpa melalui proses persidangan, pembuktian terbalik maupun proses lainnya. Produsen/pelaku usaha harus membayar ganti rugi terhadap konsumen atas kerugian yang dideritanya, terutama apabila kerugian tersebut terhadap badan dan jiwa manusia.

13) Pendapatnya tentang penerapan prinsip srict liability adalah jika kita menghadapi permasalahan sudah barang tentu upaya untuk menyelesaikan masalah tersebut harus menggunakan cara-cara yang sebanding. Perumpamaan yang diberikan adalah tidak perlu bagi kita untuk menggunakan peluru kendali untuk memusnahkan seekor semut. Menurutnya, dari berbagai macam faktor yang mendukung iklim hukum perlindungan konsumen di Belanda, maka menurutnya Belanda belum sampai pada titik untuk harus menerapkan prinsip strict liability dalam undang-undangnya.

14) Opini selanjutnya yang disampaikan oleh beliau adalah pemberlakuan strict liability dalam suatu negara secara garis besar didasarkan pada kebutuhan negara yang bersangkutan, perilaku dari masyarakat negara yang bersangkutannya dan budaya hukum yang melatarbelakanginya. Berbeda suatu negara dengan negara lainnya pun mengakibatkan berbedanya permasalahan yang dihadapi. Namun demikian penekanan yang harus diperhatikan adalah terhadap perlindungan hak konsumen dan produsen serta aspek untuk meningkatkan kesejahteraan bangsa dan negara.

Faktor mendasar yang harus diperhatikan oleh seluruh pihak termasuk pemerintah beserta seluruh jajarannya adalah untuk selalu berupaya belajar dari 
permasalahan yang ada, selalu mawas diri terhadap produk-produk legislatif terutama terhadap peristiwa begitu banyaknya peraturan perundang-undangan yang diberlakukan secara serempak (yang mengatur substansi yang kurang lebih sama), karena jika sampai terjadi demikian kita akan sampai pada titik bahwa tidak semua hukum yang berlaku merefleksikan cita keadilan. Belanda tidak menganut prinsip strict liability tetapi justru hanya dengan menundukan dirinya pada ketentuan product liability-nya. Hal ini sebagaimana diatur dalam Kitab Undang-Undang Hukum Perdata Belanda yang baru yang mengatur sebagai berikut:

\section{Afdeling 3/Section 3/Bagian 3 \\ Produktenaansprakelijkheid/Product Liability/ \\ Tanggung Jawab Produk}

\begin{tabular}{|c|c|c|}
\hline Belanda & Inggris & Indonesia \\
\hline \multicolumn{3}{|l|}{ Artikel 185} \\
\hline $\begin{array}{l}\text { 1. De producent is } \\
\text { aansprakelijk voor de } \\
\text { schade veroorzaakt door } \\
\text { een gebrek in zijn produkt, } \\
\text { tenzij: }\end{array}$ & $\begin{array}{l}\text { 1. The producer } \\
\text { shall not be liable } \\
\text { for the damage } \\
\text { caused by a defect } \\
\text { in his product, if: }\end{array}$ & $\begin{array}{l}\text { 1. Produsen tidak } \\
\text { bertanggung jawab untuk } \\
\text { kerugian yang } \\
\text { diakibatkan dari cacatnya } \\
\text { suatu barang, jika: }\end{array}$ \\
\hline $\begin{array}{l}\text { a. hij het produkt niet in } \\
\text { het verkeer heeft } \\
\text { gebracht; } \\
\text { b. het, gelet op de } \\
\text { omstandigheden, } \\
\text { aannemelijk is dat het } \\
\text { gebrek dat de schade } \\
\text { heeft veroorzaakt, niet } \\
\text { bestond op het tijdstip } \\
\text { waarop hij het } \\
\text { produkt in het verkeer } \\
\text { heeft gebracht, dan } \\
\text { wel dat dit gebrek } \\
\text { later is ontstaan; } \\
\text { het produkt noch voor } \\
\text { de verkoop of voor } \\
\text { enige andere vorm } \\
\text { van verspreiding met } \\
\text { een economisch doel }\end{array}$ & $\begin{array}{l}\text { a. he did not put } \\
\text { the product } \\
\text { into } \\
\text { circulation; } \\
\text { b. having regard } \\
\text { to the } \\
\text { circumstances, } \\
\text { it is probable } \\
\text { that the defect } \\
\text { which caused } \\
\text { the damage did } \\
\text { not exist at the } \\
\text { time when the } \\
\text { product was } \\
\text { put into } \\
\text { circulation by } \\
\text { him or that the } \\
\text { defect came } \\
\text { into being }\end{array}$ & $\begin{array}{l}\text { a. barang tersebut bukan } \\
\text { untuk diedarkan; } \\
\text { b. dengan } \\
\text { memperhatikan } \\
\text { kondisi yang ada, } \\
\text { dimungkinkan bahwa } \\
\text { cacat yang } \\
\text { menyebabkan } \\
\text { kerugian tidak ada } \\
\text { pada saat barang } \\
\text { tersebut diedarkan } \\
\text { oleh produsennya atau } \\
\text { cacat itu baru timbul } \\
\text { setelahnya; tersebut } \\
\text { barang untuk } \\
\text { diproduksi segala } \\
\text { diobral atau sis } \\
\text { bentuk distribusi yang } \\
\text { bertujuan ekonomis }\end{array}$ \\
\hline
\end{tabular}


van de producent is vervaardigd, noch is vervaardigd verspreid in het kader van de uitoefening van zijn beroep of bedrijf;

d. het gebrek een gevolg is van het feit dat het produkt overeenstemming is met dwingende overheidsvoorschrifte $n$;

e. het op grond van de stand van de wetenschappelijke en technische kennis op het tijdstip waarop hij het produkt in het verkeer bracht, onmogelijk was het bestaan van het gebrek te ontdekken;

f. wat de producent van een grondstof of fabrikant van een onderdeel betreft, het gebrek is te wijten aan het ontwerp van het produkt waarvan de grondstof of het onderdeel een bestanddeel vormt, dan wel aan de instructies die door de fabrikant van het produkt zijn verstrekt. afterwards;

c. the product

was neither

manufactured

by the

producer for

sale or any

form

of

distribution for

economic

purposes nor manufactured

or distributed

by him in the

conduct of his

profession or

business;

d. the defect is

due to

compliance of

the product

with

mandatory

regulations

issued by the public

authorities;

e. the state of scientific and technical

knowledge at the same time when he put the product into circulation was not such as to enable the existence of the defect to be discovered;

$f$. in the case of $a$ product of raw material or the manufacturer

of component, the bukan diproduksi atau didistribusikan untuk melakukan profesinya atau menjalankan bisnisnya;

d. kerusakan dari barang tersebut ditimbulkan karena kewajiban untuk mengikuti suatu peraturan yang dikeluarkan oleh pejabat yang berwenang;

e. pengetahuan ilmiah dan teknis suatu negara pada saat produsen mendistribusikan barangnya tidak memungkinkan produsen untuk menemukan cacat yang ada pada barang tersebut;

f. pada kasus produsen bahan-bahan mentah atau yang memproduksi suatu komponen dari suatu barang, cacat diakibatkan oleh desain atau komponen suatu produk yang terdiri dari bahan mentah atau karena telah diperintahkan oleh produsen dari barang tersebut. 


\begin{tabular}{|c|c|c|}
\hline , & $\begin{array}{l}\text { defect is } \\
\text { attributable to } \\
\text { the design of } \\
\text { the product in } \\
\text { which the raw } \\
\text { material or } \\
\text { component is } \\
\text { comprised or } \\
\text { to the } \\
\text { instructions } \\
\text { given by the } \\
\text { producer of the } \\
\text { product. }\end{array}$ & \\
\hline $\begin{array}{l}\text { 2. De aansprakelijkheid } \\
\text { van de producent wordt } \\
\text { verminderd of } \\
\text { opgeheven rekening } \\
\text { houdende met alle } \\
\text { omstandigheden, indien } \\
\text { de schade is } \\
\text { veroorzaakt zowel door } \\
\text { een gebrek in het } \\
\text { produkt als door schuld } \\
\text { van de benadeelde of } \\
\text { een persoon voor wie de } \\
\text { benadeelde } \\
\text { aansprakelijk is. }\end{array}$ & $\begin{array}{l}\text { 2. The liability of } \\
\text { the producer is } \\
\text { reduced or } \\
\text { extinguished, } \\
\text { having regard to } \\
\text { all the } \\
\text { circumstances, if } \\
\text { the damage has } \\
\text { been caused both } \\
\text { by a defect in the } \\
\text { product and by } \\
\text { the fault of the } \\
\text { injured person or } \\
\text { of a person for } \\
\text { whom the injured } \\
\text { person is liable. }\end{array}$ & 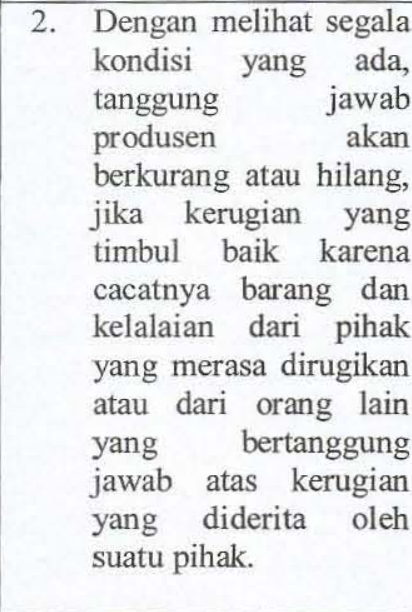 \\
\hline $\begin{array}{l}\text { 3. aansprakelijkheid } \\
\text { van de producent wordt } \\
\text { niet verminderd, indien } \\
\text { de schade is } \\
\text { veroorzaakt zowel door } \\
\text { een gebrek in het } \\
\text { produkt als door de } \\
\text { gedraging van een } \\
\text { derde. }\end{array}$ & $\begin{array}{l}\text { 3. The liability of } \\
\text { the producer is } \\
\text { not reduced if the } \\
\text { damage has been } \\
\text { caused both by a } \\
\text { defect in the } \\
\text { product and by } \\
\text { the conduct of a } \\
\text { thirdperson. }\end{array}$ & 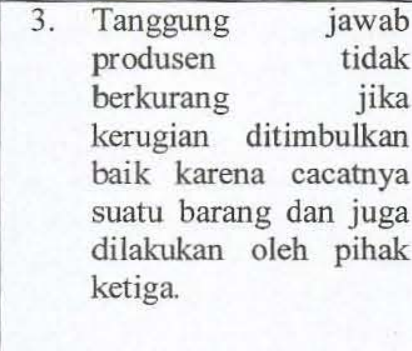 \\
\hline \multicolumn{3}{|l|}{ Artikel 186} \\
\hline $\begin{array}{l}\text { 1. Een produkt is gebrekkig, } \\
\text { indien het niet de } \\
\text { veiligheid biedt die men } \\
\text { daarvan mag } \\
\text { verwachten, }\end{array}$ & $\begin{array}{l}\text { A. product is } \\
\text { defective when it } \\
\text { does not provide } \\
\text { the safety which a } \\
\text { person is entitled }\end{array}$ & $\begin{array}{l}\text { 1. Suatu barang dikatakan } \\
\text { cacat jika tidak } \\
\text { menyediakan segi } \\
\text { keamanan kepada pihak } \\
\text { yang berhak, termasuk }\end{array}$ \\
\hline
\end{tabular}




\begin{tabular}{|c|c|c|}
\hline $\begin{array}{l}\text { omstandigheden in } \\
\text { aanmerking genomen en } \\
\text { in het bijzonder: } \\
\text { a. de presentatie van het } \\
\text { produkt; } \\
\text { b. het redelijkerwijs te } \\
\text { verwachten gebruik } \\
\text { van het produkt; } \\
\text { c. het tijdstip waarop } \\
\text { het produkt in het } \\
\text { verkeer werd } \\
\text { gebracht. }\end{array}$ & $\begin{array}{l}\text { to expect, taking } \\
\text { all circumstances } \\
\text { into account, } \\
\text { including: } \\
\text { a. the presentation } \\
\text { of the } \\
\text { product; } \\
\text { the use to } \\
\text { which it } \\
\text { could } \\
\text { reasonably } \\
\text { be expected } \\
\text { that the } \\
\text { product } \\
\text { would be } \\
\text { put; the time } \\
\text { the when the } \\
\text { when product was } \\
\text { put into } \\
\text { circulation. }\end{array}$ & $\begin{array}{l}\text { juga diantaranya: } \\
\text { a. penjelasan dari suatu } \\
\text { produk; } \\
\text { b. penjelasan tentang } \\
\text { bagaimana dan } \\
\text { dimana suatu barang } \\
\text { harus ditempatkan; } \\
\text { c. kapan barang } \\
\text { tersebut diedarkan. }\end{array}$ \\
\hline $\begin{array}{l}\text { 2. Een produkt mag niet } \\
\text { als gebrekkig worden } \\
\text { beschouwd uitsluitend } \\
\text { omdat nadien een beter } \\
\text { produkt in het verkeer is } \\
\text { gebracht. }\end{array}$ & $\begin{array}{l}\text { 2. A product shall } \\
\text { not be considered } \\
\text { defective for the } \\
\text { sole reason that a } \\
\text { better product is } \\
\text { subsequently put } \\
\text { into circulation. }\end{array}$ & $\begin{array}{l}\text { 2. Suatu barang tidak } \\
\text { bisa dikatakan cacat apabila } \\
\text { produk yang diedarkan } \\
\text { setelahnya lebih baik dari } \\
\text { yang sebelumnya. }\end{array}$ \\
\hline \multicolumn{3}{|l|}{ Artikel 187} \\
\hline $\begin{array}{l}\text { 1. Onder product wordt } \\
\text { voor de toepassing van } \\
\text { deze afdeling verstaan } \\
\text { een roerende zaak, ook } \\
\text { nadat deze een } \\
\text { bestanddeel is gaan } \\
\text { vormen van een andere } \\
\text { roerende of onroerende } \\
\text { zaak, alsmede } \\
\text { elektriciteit }\end{array}$ & $\begin{array}{l}\text { 1. For the purposes } \\
\text { of this Section, a } \\
\text { 'product' shall } \\
\text { mean a movable } \\
\text { thing, even after } \\
\text { its incorporation } \\
\text { into another } \\
\text { movable or } \\
\text { immovable thing, } \\
\text { as well as } \\
\text { electricity. }\end{array}$ & $\begin{array}{l}\text { 1. Berkaitan dengan } \\
\text { bab ini, "barang" yang } \\
\text { dimaksud adalah benda } \\
\text { bergerak, walaupun } \\
\text { kemudian benda bergerak } \\
\text { digabungkan dengan benda } \\
\text { tidak bergerak, termasuk } \\
\text { juga aliran listrik. }\end{array}$ \\
\hline $\begin{array}{l}\text { 2. Onder "producent" } \\
\text { wordt voor de } \\
\text { toepassing van artikel }\end{array}$ & $\begin{array}{l}\text { 2. For the purpose } \\
\text { of Articles } 185 \text { to } \\
193 \text {, inclusive, a }\end{array}$ & $\begin{array}{l}2 . \quad \text { Berkaitan dengan } \\
\text { Pasal } 185 \text { sampai Pasal 193, } \\
\text { "produsen" yang dimaksud }\end{array}$ \\
\hline
\end{tabular}




\begin{tabular}{|c|c|c|c|c|}
\hline & $\begin{array}{l}185 \text { tot en met } 193 \\
\text { verstaan de fabrikant } \\
\text { van een eindprodukt, de } \\
\text { producent van een } \\
\text { grondstof of de } \\
\text { fabrikant van een } \\
\text { onderdeel, alsmede een } \\
\text { ieder die zich als } \\
\text { producent presenteert } \\
\text { door zijn naam, zijn } \\
\text { merk of een ander } \\
\text { onderscheidingsteken } \\
\text { op het produkt aan te } \\
\text { brengen. }\end{array}$ & & $\begin{array}{l}\text { 'producer' means } \\
\text { the manufacturer } \\
\text { of a finished } \\
\text { product, the } \\
\text { producer of raw } \\
\text { material, or the } \\
\text { producer of a } \\
\text { component part } \\
\text { and any person } \\
\text { who, by putting } \\
\text { his name, trade } \\
\text { mark or other } \\
\text { distinguishing } \\
\text { feature on the } \\
\text { product presents } \\
\text { himself as its } \\
\text { producer. }\end{array}$ & $\begin{array}{l}\text { adalah termasuk pabrik yang } \\
\text { memproduksi barang jadi, } \\
\text { produsen bahan-bahan } \\
\text { mentah, atau produsen dari } \\
\text { komponen suatu barang dan } \\
\text { juga setiap orang yang } \\
\text { memberikan nama, merk } \\
\text { atau ciri khas pada suatu } \\
\text { barang yang membuat } \\
\text { dirinya dianggap sebagai } \\
\text { produsen dari barang } \\
\text { tersebut. }\end{array}$ \\
\hline 3. & $\begin{array}{l}\text { Onverminderd de } \\
\text { aansprakelijkheid van } \\
\text { de producent, wordt } \\
\text { een ieder die een } \\
\text { produkt in de Europese } \\
\text { Economische Ruimte } \\
\text { invoert om dit te } \\
\text { verkopen, te verhuren, } \\
\text { te leasen of anderszins } \\
\text { te verstrekken in het } \\
\text { kader van zijn } \\
\text { commerciële producent; zijn } \\
\text { activiteiten, beschouwd } \\
\text { als prodi is } \\
\text { aansprakelijkheid } \\
\text { dezelfde als die van de } \\
\text { producent. }\end{array}$ & 3. & $\begin{array}{l}\text { Without prejudice } \\
\text { to the liability of } \\
\text { the producer, any } \\
\text { person who } \\
\text { imports a product } \\
\text { into the } \\
\text { European } \\
\text { Economic Area } \\
\text { for sale, hire, } \\
\text { leasing or for any } \\
\text { form of } \\
\text { distribution in the } \\
\text { conduct of his } \\
\text { commercial } \\
\text { activities, shall } \\
\text { be deemed to be } \\
\text { a producer, and } \\
\text { shall } \\
\text { responsible as a } \\
\text { producer. }\end{array}$ & $\begin{array}{l}\text { 3. Tanpa mengurangi } \\
\text { tanggung jawab produsen, } \\
\text { setiap orang yang } \\
\text { mengimpor barang ke Zona } \\
\text { Ekonomi Eropa untuk } \\
\text { menjual, menyewa, } \\
\text { mengontrak atau segala } \\
\text { bentuk distribusi untuk } \\
\text { melakukan kegiatan } \\
\text { bisnisnya, dapat dikatakan } \\
\text { sebagai produsen, dan dapat } \\
\text { diminta } \\
\text { pertanggungjawabannya } \\
\text { sebagai seorang produsen. }\end{array}$ \\
\hline 4. & $\begin{array}{l}\text { Indien niet kan worden } \\
\text { vastgesteld wie de } \\
\text { producent van het } \\
\text { produkt is, wordt elke } \\
\text { leverancier als } \\
\text { producent ervan } \\
\text { beschouwd, tenzij hij de } \\
\text { benadeelde binnen een }\end{array}$ & 4 & $\begin{array}{l}\text { Where the } \\
\text { manufacturer of } \\
\text { a product cannot } \\
\text { be identified, } \\
\text { each supplier } \\
\text { shall be treated } \\
\text { as its producer, } \\
\text { unless he informs }\end{array}$ & $\begin{array}{l}\text { 4. Jika pabrik dari } \\
\text { suatu barang tidak bisa } \\
\text { diidentifikasi, masing- } \\
\text { masing penyalur barang bisa } \\
\text { dianggap sebagai produsen, } \\
\text { kecuali dia memberitahukan } \\
\text { identitas siapa produsennya } \\
\text { atau pihak mana yang }\end{array}$ \\
\hline
\end{tabular}




\begin{tabular}{|c|c|c|}
\hline $\begin{array}{l}\text { redelijke termijn de } \\
\text { identiteit meedeelt van } \\
\text { de producent of van } \\
\text { degene die hem het } \\
\text { produkt heeft geleverd. } \\
\text { Indien ten aanzien van } \\
\text { een in de Europese } \\
\text { Economische Ruimte } \\
\text { geümporteerd produkt } \\
\text { niet kan worden } \\
\text { vastgesteld wie de } \\
\text { importeur van dat } \\
\text { produkt is, wordt } \\
\text { eveneens elke } \\
\text { leverancier als } \\
\text { producent ervan } \\
\text { beschouwd, tenzijhij de } \\
\text { benadeelde binnen een } \\
\text { redelijke termijn de } \\
\text { identiteit meedeelt van } \\
\text { de importeur in de } \\
\text { Europese Economische } \\
\text { Ruimte of van een } \\
\text { leverancier binnen de } \\
\text { Europese Economische } \\
\text { Ruimte die hem het } \\
\text { produkt heeft geleverd. }\end{array}$ & $\begin{array}{l}\text { the injured party } \\
\text { within a } \\
\text { reasonable time } \\
\text { of the identity of } \\
\text { the producer or } \\
\text { of the person who } \\
\text { supplied him with } \\
\text { the product. } \\
\text { Where, with } \\
\text { respect to a } \\
\text { product imported } \\
\text { into the } \\
\text { European } \\
\text { Economic Area, } \\
\text { its importer } \\
\text { cannot be } \\
\text { identified, each } \\
\text { supplier thereof } \\
\text { is likewise } \\
\text { considered as a } \\
\text { producer, unless } \\
\text { he informs the } \\
\text { injured person } \\
\text { within the } \\
\text { reasonable time } \\
\text { of the identity of } \\
\text { the importer into } \\
\text { the European } \\
\text { Economic Area } \\
\text { or of a supplier } \\
\text { within the } \\
\text { European } \\
\text { Economic Area } \\
\text { who supplied the } \\
\text { product to him. }\end{array}$ & $\begin{array}{l}\text { menyalurkan barang } \\
\text { tersebut. Jika terhadap } \\
\text { barang yang diimpor ke } \\
\text { Zona Ekonomi Eropa tidak } \\
\text { dapat didentifikasikan, } \\
\text { masing-masing penyalurnya } \\
\text { akan dianggap seperti } \\
\text { halnya produsen kecuali } \\
\text { pihaknya memberitahukan } \\
\text { kepada pihak yang dirugikan } \\
\text { dalam waktu yang masih } \\
\text { dapat dimengerti perihal } \\
\text { identitas dari importir } \\
\text { kepada Wilayah Ekonomi } \\
\text { Eropa atau penyalur dalam } \\
\text { Wilayah Ekonomi Eropa } \\
\text { yang menyalurkan produk } \\
\text { tersebut kepada pihaknya. }\end{array}$ \\
\hline \multicolumn{3}{|l|}{ Artikel 188} \\
\hline $\begin{array}{l}\text { De benadeelde moet de } \\
\text { schade, het gebrek en het } \\
\text { oorzakelijk verband tussen } \\
\text { het gebrek en de schade } \\
\text { bewijzen. }\end{array}$ & $\begin{array}{l}\text { The injured person } \\
\text { shall be required to } \\
\text { prove the damage, } \\
\text { the defect and the } \\
\text { causal relationship } \\
\text { between defect and } \\
\text { damage. }\end{array}$ & $\begin{array}{l}\text { Pihak yang dirugikan harus } \\
\text { dapat membuktikan } \\
\text { kerugian yang dialami, } \\
\text { kecacatan barang tersebut } \\
\text { dan hubungan kausalitas } \\
\text { antara kerugian yang } \\
\text { ditimbulkan dari kecacatan } \\
\text { suatu barang. }\end{array}$ \\
\hline & & \\
\hline
\end{tabular}




\begin{tabular}{|c|c|c|}
\hline $\begin{array}{l}\text { Indien verschillende } \\
\text { personen op grond van } \\
\text { artikel 185, eerste lid, } \\
\text { aansprakelijk zijn voor } \\
\text { dezelfde schade, is elk } \\
\text { hunner voor het geheel } \\
\text { aansprakelijk. }\end{array}$ & $\begin{array}{l}\text { If, on the basis of } \\
\text { Article } 185, \\
\text { paragraph } 1 \text {, several } \\
\text { persons are liable } \\
\text { for the same } \\
\text { damage, each of } \\
\text { them shall be liable } \\
\text { for the whole. }\end{array}$ & $\begin{array}{l}\text { Berdasarkan Pasal } 185 \text {, } \\
\text { ayat 1, beberapa pihak } \\
\text { dapat bertanggung jawab } \\
\text { atas kerugian yang } \\
\text { ditimbulkan, dan masing- } \\
\text { masing pihak tersebut harus } \\
\text { bertanggung jawab secara } \\
\text { sepenuhnya. }\end{array}$ \\
\hline \multicolumn{3}{|l|}{ Artikel 190} \\
\hline $\begin{array}{l}\text { 1. De aansprakelijkheid, } \\
\text { bedoeld in artikel 185, } \\
\text { eerste lid, bestaat voor: } \\
\text { a. schade door dood } \\
\text { of lichamelijk } \\
\text { letsel; } \\
\text { b. schade door het } \\
\text { produkt } \\
\text { toegebracht aan } \\
\text { een andere zaak die } \\
\text { gewoonlijk voor } \\
\text { gebruik of verbruik } \\
\text { in de privésfeer is } \\
\text { bestemd en door de } \\
\text { benadeelde ook } \\
\text { hoofdzakelijk in de } \\
\text { privésfeer is } \\
\text { gebruikt af } \\
\text { verbruikt, met } \\
\text { toepassing van een } \\
\text { franchise ten belope } \\
\text { van } 1500 .\end{array}$ & $\begin{array}{l}\text { The liability } \\
\text { referred to in } \\
\text { Article 185, } \\
\text { paragraph } \\
\text { extends to: } \\
\text { a. damage } \\
\text { caused by } \\
\text { death or } \\
\text { personal } \\
\text { injuries; } \\
\text { damage } \\
\text { caused by } \\
\text { the product } \\
\text { to another } \\
\text { thing, which } \\
\text { is usually } \\
\text { intended for } \\
\text { private use } \\
\text { or } \\
\text { consumption } \\
\text {, and which } \\
\text { has indeed } \\
\text { been used or } \\
\text { consumed by } \\
\text { the person } \\
\text { suffering the } \\
\text { loss, } \\
\text { principally } \\
\text { for private } \\
\text { purposes, } \\
\text { with an } \\
\text { excess or } \\
\text { deductible of } \\
\text { } \text { } 500 . \\
\text { b. }\end{array}$ & $\begin{array}{l}\text { 1. Tanggung jawab yang } \\
\text { dimaksud dalam Pasal } \\
\text { 185, ayat } 1 \text { termasuk } \\
\text { terhadap: } \\
\text { a. kerugian yang } \\
\text { ditimbulkan dari } \\
\text { kematian atau } \\
\text { kecelakaan } \\
\text { seseorang; } \\
\text { kerugian yang } \\
\text { ditimbulkan dari } \\
\text { suatu barang } \\
\text { terhadap barang } \\
\text { lainnya, dimana } \\
\text { biasanya } \\
\text { dikonsumsi untuk } \\
\text { keperluan pribadi, } \\
\text { dan yang sering } \\
\text { digunakan atau } \\
\text { dikonsumsi oleh } \\
\text { orang yang } \\
\text { mengalami } \\
\text { kerugian, terutama } \\
\text { untuk kebutuhan } \\
\text { pribadinya, yang } \\
\text { bernilai lebih dari } \\
€ 500 .\end{array}$ \\
\hline Het bedrag genoemd in & amount & Jumlah \\
\hline
\end{tabular}




\begin{tabular}{|c|c|c|}
\hline $\begin{array}{l}\text { het eerste lid wordt bij } \\
\text { algemene maatregel } \\
\text { van bestuur aangepast, } \\
\text { indien op grond van } \\
\text { artikel 18, tweede lid, } \\
\text { van de EEG-richtlijn } \\
\text { van } 25 \text { juli } 1985 \\
\text { (PbEG nr. L 210) de in } \\
\text { die richtlijn genoemde } \\
\text { bedragen worden } \\
\text { herzien. }\end{array}$ & $\begin{array}{l}\text { stated in } \\
\text { paragraph } 1 \\
\text { may be adjusted } \\
\text { by Regulation } \\
\text { if, on the basis } \\
\text { of Article } 18 \text {, } \\
\text { paragraph } 2 \text { of } \\
\text { the EEC } \\
\text { Directive of } 25 \\
\text { July 1985 } \\
\text { (OJEC L 210), } \\
\text { the amounts } \\
\text { mentioned in } \\
\text { that Directive } \\
\text { are revised. }\end{array}$ & $\begin{array}{l}\text { disebutkan pada ayat } 1 \\
\text { dapat disesuaikan } \\
\text { dengan peraturan yang } \\
\text { ada jika berdasarkan } \\
\text { Pasal } 18 \text { ayat } 2 \text { dari } \\
\text { Perintah EEC pada } \\
\text { tanggal } 25 \text { Juli } 1985 \\
\text { (OJEC L 210), telah } \\
\text { diubah. }\end{array}$ \\
\hline \multicolumn{3}{|l|}{ Artikel 191} \\
\hline $\begin{array}{l}\text { 1. De rechtsvordering tot } \\
\text { schadevergoeding van } \\
\text { de benadeelde tegen de } \\
\text { producent ingevolge } \\
\text { artikel 185, eerste lid, } \\
\text { verjaart door verloop } \\
\text { van drie jaren na de } \\
\text { aanvang van de dag, } \\
\text { volgende op die waarop } \\
\text { de benadeelde met de } \\
\text { schade, het gebrek en de } \\
\text { identiteit van de } \\
\text { producent bekend is } \\
\text { geworden of had moeten } \\
\text { worden. }\end{array}$ & $\begin{array}{l}\text { 1. A right of action } \\
\text { for damages by } \\
\text { the injured } \\
\text { person against } \\
\text { the producer } \\
\text { pursuant to } \\
\text { Article 185, } \\
\text { paragraph } 1 \text {, is } \\
\text { prescribed by } \\
\text { the expiry of } \\
\text { three years from } \\
\text { the beginning of } \\
\text { the day } \\
\text { following that } \\
\text { on which the } \\
\text { injured person } \\
\text { became or } \\
\text { should have } \\
\text { become aware } \\
\text { of the damage, } \\
\text { the defect and } \\
\text { the identity of } \\
\text { the producer. }\end{array}$ & 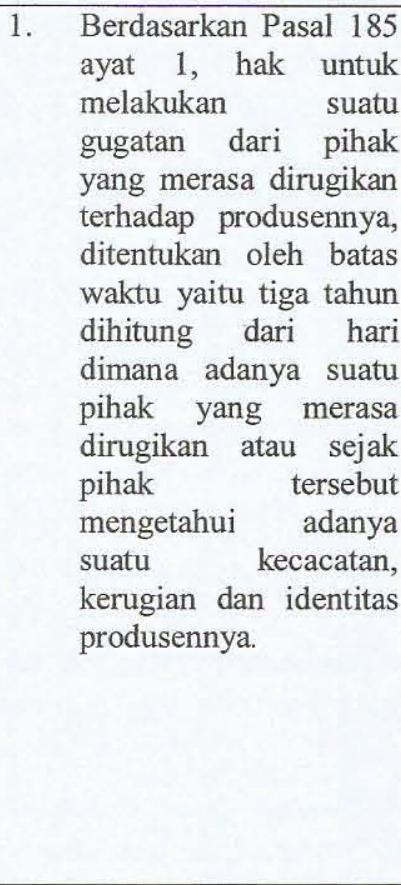 \\
\hline $\begin{array}{l}\text { Het recht op } \\
\text { schadevergoeding van } \\
\text { de benadeelde jegens de } \\
\text { producent ingevolge } \\
\text { artikel } 185 \text {, eerste lid, }\end{array}$ & $\begin{array}{l}\text { 2. The right to } \\
\text { damages of the } \\
\text { injured person } \\
\text { against the } \\
\text { producer }\end{array}$ & $\begin{array}{l}\text { 2. Berdasarkan Pasal } 185 \\
\text { ayat 1, hak untuk } \\
\text { mendapat ganti rugi } \\
\text { oleh suatu pihak yang } \\
\text { merasa dirugikan }\end{array}$ \\
\hline
\end{tabular}




\begin{tabular}{|c|c|c|c|c|}
\hline & $\begin{array}{l}\text { vervalt door verloop } \\
\text { van tien jaren na de } \\
\text { aanvang van de dag, } \\
\text { volgende op die waarop } \\
\text { de producent de zaak } \\
\text { die de schade heeft } \\
\text { veroorzaakt, in het } \\
\text { verkeer heeft gebracht. } \\
\text { Hetzelfde geldt voor het } \\
\text { recht van een derde die } \\
\text { mede voor de schade } \\
\text { aansprakelijk is, terzake } \\
\text { van regres jegens de } \\
\text { producent. }\end{array}$ & & $\begin{array}{l}\text { pursuant to } \\
\text { Article } 185 \text {, } \\
\text { paragraph } 1 \text { is } \\
\text { extinguished on } \\
\text { expiry of ten } \\
\text { years from the } \\
\text { beginning of the } \\
\text { day following } \\
\text { that on which the } \\
\text { producer put the } \\
\text { thing which } \\
\text { caused the } \\
\text { damage into } \\
\text { circulation. The } \\
\text { same applies to } \\
\text { the right of a } \\
\text { third person who } \\
\text { is also liable for } \\
\text { the damages, } \\
\text { with respect to } \\
\text { his right of } \\
\text { recourse against } \\
\text { the producer. }\end{array}$ & $\begin{array}{l}\text { terhadap seorang } \\
\text { produsen dapat hilang } \\
\text { jika telah lewat dari } \\
\text { sepuluh tahun dihitung } \\
\text { dari saat produsen itu } \\
\text { mulai mengedarkan } \\
\text { barangnya. Hal yang } \\
\text { sama diterapkan } \\
\text { terhadap hak pihak } \\
\text { ketiga yang juga turut } \\
\text { bertanggung jawab atas } \\
\text { kerugian yang } \\
\text { ditimbulkan, sebagai } \\
\text { cara lain untuk } \\
\text { menggugat produsen. }\end{array}$ \\
\hline \multicolumn{5}{|c|}{ Artikel 192} \\
\hline & $\begin{array}{l}\text { De aansprakelijkheid } \\
\text { van de producent uit } \\
\text { hoofde van deze } \\
\text { afdeling kan jegens de } \\
\text { benadeelde niet } \\
\text { worden uitgesloten of } \\
\text { beperkt. }\end{array}$ & & $\begin{array}{l}\text { The liability of } \\
\text { the producer } \\
\text { pursuant to this } \\
\text { Section may not } \\
\text { be excluded or } \\
\text { limited with } \\
\text { respect to the } \\
\text { injured person. }\end{array}$ & $\begin{array}{l}\text { Berdasarkan bab ini, } \\
\text { tanggung jawab } \\
\text { produsen tidak terbatas } \\
\text { terhadap pihak yang } \\
\text { merasa dirugikan. }\end{array}$ \\
\hline 2. & $\begin{array}{l}\text { Is jegens de benadeelde } \\
\text { tevens een derde } \\
\text { aansprakelijk die het } \\
\text { produkt niet gebruikt in } \\
\text { de uitoefening van een } \\
\text { beroep of bedrijf, dan } \\
\text { kan niet ten nadele van } \\
\text { die derde worden } \\
\text { afgeweken van de } \\
\text { regels inzake het } \\
\text { regres. }\end{array}$ & & $\begin{array}{l}\text { Where a third } \\
\text { person, who } \\
\text { does not use the } \\
\text { product in the } \\
\text { conduct of a } \\
\text { profession or } \\
\text { business, is also } \\
\text { liable towards } \\
\text { the injured } \\
\text { person, there } \\
\text { shall be no } \\
\text { derogation, to }\end{array}$ & $\begin{array}{l}\text { 2. Terhadap pihak ketiga, } \\
\text { yang tidak } \\
\text { menggunakan barang } \\
\text { untuk melakukan suatu } \\
\text { profesi atau bisnisnya, } \\
\text { juga turut bertanggung } \\
\text { jawab terhadap pihak } \\
\text { yang merasa dirugikan, } \\
\text { tidak ada } \\
\text { penyampingan atas } \\
\text { kerugian yang dialami } \\
\text { oleh pihak ketiga }\end{array}$ \\
\hline
\end{tabular}




\begin{tabular}{|c|c|c|}
\hline & $\begin{array}{l}\text { the detriment of } \\
\text { that third } \\
\text { person, from the } \\
\text { rules regarding } \\
\text { the right of } \\
\text { recourse. }\end{array}$ & $\begin{array}{lr}\text { tersebut, } & \text { berdasarkan } \\
\text { ketentuan } & \text { yang } \\
\text { mengaturnya. } & \end{array}$ \\
\hline \multicolumn{3}{|l|}{ Artikel 193} \\
\hline $\begin{array}{l}\text { Het recht op } \\
\text { schadevergoeding jegens de } \\
\text { producent uit hoofde van } \\
\text { deze afdeling komt de } \\
\text { benadeelde toe, } \\
\text { onverminderd alle andere } \\
\text { rechten of vorderingen. }\end{array}$ & $\begin{array}{l}\text { The right to } \\
\text { damages of the } \\
\text { injured person } \\
\text { against the producer } \\
\text { pursuant to this } \\
\text { Section, is without } \\
\text { prejudice to all } \\
\text { other rights or } \\
\text { actions. }\end{array}$ & $\begin{array}{l}\text { Berdasarkan bab ini, hak } \\
\text { untuk mendapat ganti rugi } \\
\text { oleh pihak yang merasa } \\
\text { dirugikan dari produsen } \\
\text { tidak boleh mengurangi } \\
\text { hak-hak lainnya. }\end{array}$ \\
\hline
\end{tabular}

Bab tentang Tanggung Jawab Produk dalam Kitab Undang-Undang Hukum Perdata Belanda berupaya mengatur secara semaksimal mungkin untuk memberikan aturan main terhadap produsen dan konsumen secara bersamaan. Hal ini pun ditunjukan antara lain dengan aspek pertanggungjawaban atas produk yang tidak melulu berada ditangan produsen tetapi dapat dibebankan pada pihak lain atau sama sekali tidak dibebankan kepada pihak manapun juga tergantung dari produk maupun peruntukan dari suatu produk. Tetapi dilain pihak produsen tetap dituntut untuk bertanggung jawab baik secara mandiri maupun secara bersama-sama dengan pihak lainnya yang tergabung dalam rantai distribusi produk atau mungkin juga produsen terlepas dari tanggung jawab tetapi justru salah satu pihak atau beberapa pihak yang tergabung dalam rantai distribusi untuk bertanggung jawab atas kerugian yang diderita oleh konsumen.

Ketentuan tentang tanggung jawab produk sebagaimana di atur dalam Kitab Undang-Undang Hukum Perdata Belanda pun terintegrasi dengan ketentuan-ketentuan umum perlindungan konsumen yang berlaku pada masyarakat Uni Eropa. Dengan kata lain ketentuan tanggung jawab produk dalam Kitab Undang-Undang Hukum Perdata merupakan lex specialis dari ketentuan umum perlindungan konsumen yang berlaku pada masyarakat Uni Eropa. Seperti yang juga telah dikemukakan oleh Prof. Jan van Dalen peraturan tentang tanggung jawab produk ini juga turut terintegrasi dengan peraturan perundang-undangan lainnya yang berhubungan dengan lingkup perlindungan 
konsumen antara lain seperti hukum tentang makanan, pariwisata, telekomunikasi dan lain sebagainya.

\section{Kesimpulan}

\section{Informasi dan Referensi Product Liability dan Strict Liability di Indonesia}

a. Minimnya literatur tentang product liability dan strict liability di Indonesia, sehingga dalam penyusunan riset informasi yang dipergunakan lebih banyak mengacu pada literatur asing.

b. Literatur tentang product liability dan strict liability memang ada tetapi dari beberapa sumber yang dijadikan sebagai referensi tidak memiliki sesuatu aspek perbedaan ataupun kebaruan yang mendasar.

\section{Pemahaman Product Liability dan Strict Liability di Indonesia}

a. Baik konsumen maupun produsen serta instansi-instansi pemerintah/ penegak hukum belum memiliki pemahaman yang memadai tentang product liability dan strict liability.

b. Kondisi belum memiliki pemahaman yang memadai tentang product liability dan strict liability ditunjang dengan tidak efektifnya keberlakuan ketentuan-ketentuan hukum perlindungan konsumen dikalangan masyarakat Indonesia, dan masih terdapat serta begitu banyaknya oknum-oknum yang tidak bertanggung jawab yang memanfaatkan keadaan yang sangat tidak kondusif ini semata-mata demi keuntungannya.

c. Pemahamannya adalah meskipun telah berlaku UUPK tetapi seringkali perkara yang diajukan ke pengadilan masih mempergunakan ketentuan-ketentuan berdasarkan segala sesuatu pasal yang terdapat dalam KUHPerdata. Oleh karenanya hal ini mengindikasikan bahwa aparat penegak hukum belum memiliki pengetahuan yang memadai tentang dalil-dalil hukum yang terdapat dalam UUPK untuk dapat dipergunakan sebagai dasar gugatan dalam perkara-perkara sengketa konsumen.

d. Indonesia tidak terdapat payung hukum yang berlaku dalam tingkat regional. Lebih lanjut lagi Indonesia masih termasuk sebagai negara berkembang dengan berbagai permasalahan sosial kemasyarakatan 
yang sedemikian kompleks, dimana disatu sisi menginginkan adanya perubahan yang lebih baik tetapi resistensi terhadap perubahan tersebut juga sangat besar yang berdampak pada terhambatnya kemajuan yang dicita-citakan itu sendiri.

\section{Urgensi Penerapan Strict Liability dalam Rancangan Amandemen UUPK}

a. Fakta dilapangan menunjukan bahwa penegakan tanggung jawab produk sebagaimana yang diatur dalam UUPK belum ditegakkan sebagaimana yang telah diamanatkan.

b. Begitu banyaknya kasus-kasus yang terjadi dilapangan dan tidak adanya produsen, baik dalam maupun luar negeri yang dimintakan pertanggung-jawabannya dihadapan hukum dan kasusnya diputus secara jelas dengan mendasarkan pada ketentuan-ketentuan UUPK.

c. Ketidaktahuan konsumen akan hak-haknya oleh produsen maupun rantai distribusi barang yang tidak beritikad baik dan tidak bertanggung jawab dimanfaatkan secara sewenang-wenang.

d. Hanya kasus-kasus besar yang mencuat kepermukaan yang antara lain dan tidak terbatas pada bahan bakar premium bermasalah, biskuit beracun, kosmetik dengan kandungan merkuri, tabung gas meledak, pengguna kereta rel listrik yang kerap kali naik di atap kereta, penentuan tarif bawah atau rendah oleh para perusahaan taksi, makanan yang tidak berlabel halal atau mengandung bahan transgenik, pengisian ulang air mineral tidak resmi, dan masih banyak kasus lainnya yang menunjukan bahwa prinsip tanggung jawab produk di Indonesia sangat lemah penerapannya.

e. Indonesia yang sangat rentan dalam bidang pengawasan arus masuk barang dan distribusi barang, termasuk juga terhadap siapa suatu produk tertentu dapat dan harus dipertanggungjawabkan.

f. Sementara kalangan masih memiliki anggapan bahwa peraturan prinsip tanggung jawab produk hanya norma formal saja yang tidak berlaku secara efektif dalam realitasnya.

g. Sulitnya untuk mencari perkara perselisihan product liability dan strict liability di pengadilan Indonesia karena para pihak yang bersengketa lazimnya menggunakan mekanisme sengketa perdata umum dan bukan melalui lembaga penyelesaian perselisihan sengketa konsumen. 
h. Sudah waktunya untuk mempertimbangkan diterapkan strict liability agar menjadikan produsen lebih profesional dan mawas diri.

i. Pertimbangan penerapan prinsip ini dengan memperhatikan secara seksama implikasi apa saja yang akan timbul dan patut dihindari agar ketentuan strict liability ini untuk tidak menjadi pasal sapu jagat yang dapat mencederai siapa saja tanpa terkecuali.

j. Salah satu Alasan pemberlakuan prinsip strict liability adalah dikarenakan terdapat oknum pelaku usaha yang bersifat dominan dan dapat menekan asosiasi-asosiasi untuk berpihak pada kepentingannya, sehingga UUPK tidak dapat berlaku efektif terhadapnya.

k. Para produsen dan rantai distribusi dihimbau tegas untuk memiliki tidak hanya berorientasi pada perolehan keuntungan yang tidak memperhatikan bentuk-bentuk apresiasi dan penghargaan kepada para konsumen yang telah mempergunakan dan membeli produk-produk yang dijualnya.

1. Penerapan ketentuan tanggung jawab mutlak tidak dapat diberlakukan pada semua pengusaha melainkan hanya pada kelompok-kelompok produsen tertentu. Ini bukan berarti melakukan tindakan diskriminatif tetapi justru untuk memberikan tanggung jawab lebih pada produsenprodusen besar untuk lebih bertanggung jawab terhadap produkproduknya.

m. Selain daripada itu penting untuk dipahami bagi produsen besar yang bersangkutan apabila telah melaksanakan ketentuan undang-undang, termasuk juga terhadap standarisasi tata cara penggunaan produk, komposisi dan informasi lainnya yang diberikan untuk kepentingan konsumen telah dilaksanakan, dan dilain pihak telah memiliki standar proses pembuatan yang mutakhir dan baik, maka pasal tentang tanggung jawab mutlak ini tidak akan diberlakukan terhadapnya.

n. Alasan produsen kecil dan menengah tidak termasuk sebagai subjek pengaturan tanggung jawab mutlak dikarenakan pemerintah memberikan kesempatan kepada mereka untuk mengembangkan usahanya, tetapi dengan ketentuan bahwa terhadap mereka tetap berlaku ketentuan tanggung jawab produk. Oleh karenanya produsen kecil dan menengah tidak sepenuhnya lepas dari keberlakuan UUPK. 


\section{Alternatif Penyelesaian dalam Rangka Rencana Pemberlakuan Strict Liability dalam Rancangan Amandemen UUPK}

Telah digagas ide terhadap pelanggaran product liability maupun strict liability mekanisme penggantirugiannya kepada konsumen dilakukan dengan cara melibatkan pihak asuransi.

\section{Penegakan Perlindungan Konsumen terhadap Produk yang di Konsumsi Masyarakat di Belanda}

a. Belanda dalam memberlakukan undang-undang perlindungan konsumennya dengan mengacu pada peraturan perlindungan konsumen yang berlaku bagi negara-negara Uni Eropa.

b. Perbedaan yang sangat mendasar adalah negara-negara Uni Eropa merupakan negara maju yang sangat memperhatikan kesejahteraan masyarakatnya dengan tingkat kesadaran hukum yang sangat tinggi. Pemberlakukan undang-undang perlindungan konsumen dan undangundang terkait lainnya akan lebih mudah dan efektif untuk diterapkan, oleh karena masyarakat dan pemerintah secara bersama-sama mengetahui manfaat, visi dan misi dari diberlakukannya sebuah undang-undang.

c. Penegakkan hukum tidak semata-mata dijalankan oleh para penegak hukum saja, melainkan seluruh masyarakat merupakan polisi atau para penegak hukum. Seketika anggota masyarakat menemukan adanya ketidaksesuaian maka dirinya akan tampil untuk meminta klarifikasi bahkan ganti rugi kepada para produsen.

d. Produsen, termasuk pula rantai distribusi yang memasarkan produkproduknya di Eropa sangat memperhatikan ketentuan-ketentuan yang dikeluarkan oleh masyarakat Uni Eropa, yang merupakan payung hukumnya, dan juga tunduk pada ketentuan yang khusus berlaku di negara importir.

e. Pemerintah Eropa dan masyarakatnya memiliki parameter bagi para produsen, yaitu jika produknya mau diterima untuk dipasarkan maka mereka harus memenuhi standar-standar yang telah berlaku.

f. Apabila ternyata standar-standar tersebut tidak terpenuhi, maka baik pemerintah maupun masyarakat dapat menolak produk tersebut untuk masuk ke pasaran negaranya atau bahkan Eropa.

g. Berdasarkan pada hasil studi banding di Belanda diketahui bahwa 
Belanda memberlakukan tanggung jawab produk yang sangat komprehensif, dimana makna komprehensif ini tidak hanya terbatas pada pengaturannya didalam Kitab Undang-Undang Hukum Perdata Belanda saja, melainkan ketentuan tanggung jawab produk tersebut juga menunjuk pada ketentuan-ketentuan lain seperti hukum tentang makanan, telekomunikasi, pariwisata dan lain sebagainya.

h. Tanggung jawab produk yang berlaku di Belanda sifatnya sangat integratif dengan peraturan perundang-undangan lain yang ada dan berlaku.

i. Keanggotaan Belanda sebagai salah satu masyarakat Uni Eropa menjadikan lingkup perlindungan hukum dibidang perlindungan konsumen menjadi lebih kuat, baik dalam konteks sebagai anggota sebuah komunitas ataupun dalam konteks sebagai negara yang mandiri.

j. Penegakan hukumnya telah berjalan dengan baik, maka produsen dan konsumen sepenuhnya tunduk pada ketentuan hukum perlindungan konsumen di Belanda.

k. Belanda mengambil nilai-nilai tanggung jawab produk yang sebenarnya hampir mendekati pada prinsip tanggung jawab mutlak tetapi tetap masih dalam tatanan tanggung jawab produk.

1. Tanpa terkecuali para produsen asing yang diwajibkan untuk tunduk pada peraturan tersebut, bahkan terbuka peluang manakala ternyata didapati produsen tidak mematuhi maka masyarakat Eropa tidak akan membeli produk tersebut sampai telah dilakukan perbaikan standar sesuai dengan permintaan mereka.

m. Kesadaran hukum komunitas masyarakatnya yang sudah sangat tinggi mengakibatkan peraturan perundang-undangan yang berlaku dapat berjalan secara efektif, sehingga pemerintah Belanda dengan memperhatikan pada kekuatan bangunan sosiologis dan hukum masyarakatnya, tidak memandang perlu untuk memberlakukan prinsip tanggung jawab mutlak sebagai bagian dari peraturan perundangundangannya.

n. Pemerintah memaknai kepatuhan produsen dan konsumen terhadap ketentuan yang ada sudah berjalan, maka tidak ada landasan bagi mereka untuk lebih menekan masyarakatnya dengan memaksa sampai batas maksimal sanksi yang dapat diberlakukan. Seperti yang telah kita ketahui bersama bahwa tingkat kesadaran hukum masyarakat Indonesia masih sangat lemah dan jauh dari yang diharapkan. 
o. Terdapat perbedaan yang sangat signifikan dalam penerapan perlindungan konsumen di Belanda dengan di Indonesia. Artinya kita dapat mengadopsi pola yang berlaku di Belanda atau kita justru memberlakukan prinsip tanggung jawab mutlak untuk menjawab dan mengatasi berbagai macam permasalahan yang terjadi di Indonesia.

p. Belanda dalam hal ini memiliki struktur yang dijadikan sebagai basis daripada perlindungan konsumen di Belanda menunjuk pada struktur Contract Law (BW), Public Law, dan Consumer Sales. Tanggung jawab produk diterapkan dengan menggunakan pola mata rantai. Artinya, pendekatan yang diberikan oleh pembuat undang-undang perlindungan konsumen di Belanda tidak hanya menekankan pada aspek hukum privat saja, tetapi dikarenakan produk ditujukan dan dipergunakan secara massal oleh masyarakat maka hukum publik pun turut termasuk didalamnya. Maknanya adalah tidak hanya dibatasi pada sanksi yang bersifat hukum publik, melainkan juga terdapat ketentuan-ketentuan hukum publik yang juga mengatur dan terintegrasi dengan aspek dan nilai-nilai perlindungan konsumen. Pendekatan semacam ini perlu untuk ditelaah perihal perlu atau tidaknya untuk diadopsi oleh Indonesia, khususnya dalam rangka mengoptimalkan keberlakuan undang-undang perlindungan konsumen di Indonesia. 


\section{Daftar Pustaka}

\section{Buku}

Abbas, Nurhayati. Hukum Perlindungan Konsumen dan Beberapa Aspeknya, Makalah, Disampaikan dalam Seminar Nasional Hukum Perlindungan Konsumen, Kerja Sama ELIPS Project dengan Fakultas Hukum Universitas Hasanuddin, Ujungpandang, 1996.

Cane, Peter. Economic Loss and Products Liability, in Comparative Product Liability, The British Institute of International and Comparative Law, 1986.

Dunne, J.M. van, dan van der Burght, Perbuatan Melawan Hukum, terjemahan KPH Hapsoro Jayaningprang, Dewan Kerja Sama Ilmu Hukum Belanda dengan Indonesia-Proyek Hukum Perdata, Ujungpandang, 1988.

. Pertanggungjawaban Khusus Tanggung Jawab Produk, Terjemahan Agnes M. Toar, Dewan Kerja Sama Ilmu Hukum Belanda dengan Indonesia-Proyek Hukum Perdata, Ujungpandang, 1989.

Francis, Philip. Protection Through the Law, New York: Oceana Publication, Inc., 1978.

Gunawan, Johannes. "Product Liability" dalam Hukum Bisnis Indonesia, Pro Justitia Tahun XII Nomor 2 April 1994.

Hadjon, P.M. Pengkajian Ilmu Hukum Dogmatik (Normatif), Surabaya: Fakultas Hukum Universitas Airlangga, 1994.

J. Phillips, Jerry. Product Liability, St. Paul, Minnesota: West Publishing Company, 1993.

M. Toar, Agnes. Tanggung Jawab Produk dan Sejarah Perkembangannya di Beberapa Negara. Makalah, Dewan Kerja Sama Ilmu Hukum Belanda dengan Indonesia - Proyek Hukum Perdata, Ujungpandang, 1989, dikutip dari "A Wouters, Produktie-aansprakelijkheid in de Verenigde Staten", RW 1969, no. 34: 1594.

Miru, Ahmadi. Prinsip-prinsip Perlindungan Hukum Bagi Konsumen di Indonesia, Disertasi, Program Pascasarjana Universitas Airlangga, Surabaya, 2000. 
Nieuwenhuis. Pokok-pokok Hukum Perikatan, terjemahan Djasadin Saragih, Surabaya: Universitas Airlangga, 1985.

Patrik, Purwahid. Dasar-dasar Hukum Perikatan (Perikatan Yang Lahir Dari Perjanjian dan Dari Undang-undang), Bandung: Mandar Maju, 1994.

Pistor, Khatarina, dan Phillip A. Wellons, et all. The Role of Law and Legal Institutions in Asian Economic Development 1960-1995, Oxford: University Press, 1998.

Samsul, Inosentius. Hukum Perlindungan Konsumen Kemungkinan Penerapan Tanggung Jawab Mutlak, Cetakan 1, Jakarta: Universitas Indonesia, Fakultas Hukum, Pascasarjana, 2004.

. Ringkasan Disertasi Prinsip Tanggung Jawab Mutlak Dalam Hukum Perlindungan Konsumen, Jakarta: Universitas Indonesia, Fakultas Hukum, Pascasarjana, 2003.

Shofie, Yusuf. Perlindungan Konsumen dan Instrumen-Instrumen Hukumnya, Jakarta: PT Citra Aditya Bakti, 2003.

Tebbens, H. Duintjer. International Product Liability, A Study of Comparative and International Legal Aspect of Product Liability, Netherlands: Sijthoff \& Noordhoff International Publisher, 1980.

Widjaja, Gunawan dan Ahmad Yani. Hukum tentang Perlindungan Konsumen, Jakarta: PT. Gramedia Pustaka Utama, 2003.

\section{Internet}

Tjandrasari, Heri. Badan Penyelesaian Sengketa Konsumen (BPSK) Dan Upaya Perlindungan Hukum Bagi Konsumen, $<$ http://www.pemantauperadilan.com/detil/detil.php?id=93\&tipe=opini $>$, diakses tanggal 5 Juni 2005.

$<$ http://anoons2 unair.blogspot.com/2008/06/perbandingan-prinsippertanggungjawaban.html>, diakses tanggal 24 Maret 2009.

$<$ http://ariesaja.wordpress.com/2008/12/02/merkuri-sebabkan-kulit-rusakpermanen/>, diakses tanggal 12 Februari 2008.

$<$ http://bataviase.co.id/node/400600>, diakses tanggal 4 Juni 2009. 
$<$ http://berita.liputan6.com/progsus/200611/132403/class=\%27vidico $\% 27>$, diakses tanggal 3 Desember 2007.

$<$ http://en.wikipedia.org/wiki/Corporate_governance>, diakses tanggal 3 Desember 2007.

$<$ http://en.wikipedia.org/wiki/Product_liability>, diakses tanggal 4 Juni 2009.

$<$ http://fh-unsri.info/?p=279>, diakses tanggal tanggal 4 Juni 2009.

$<$ http://regional.kompas.com/read/2010/07/26/17413943/Pabrikan.Turunkan.Ti m.Uji.BBM.Bermasalah>, diakses tanggal 4 Juni 2009.

$<$ http://rgs-yurisprudensi.blogspot.com/2009/04/penerapan-pasal-1365bw.html>, diakses tanggal 4 Juni 2009.

$<$ http://staff.blog.ui.ac.id/abdul.salam/2008/07/07/perbuatan-melawan-hukumpenguasa/>, diakses tanggal 4 Juni 2009.

$<$ http://tabloidjubi.com/index.php/edisi-cetak/advertorial/2090-peredarankosmetik-berbahaya-di-papua-memprihatinkan>, diakses tanggal 4 Juni 2009.

$<$ http://tutorial-tip-trik.blogspot.com/2010/05/bahaya-merkuri-pada-kosmetik. html $>$, diakses tanggal 4 Juni 2009.

$<$ http://web.bisnis.com/keuangan/1id81470.html>, diakses tanggal 4 Juni 2009.

$<$ http://www.beritanet.com/Education/Info-Melamin-Formalin.html $>$, diakses tanggal 4 Juni 2009.

$<$ http://www.bisnis.com/sektor-riil/otomotif/1id194753.html $>$, tanggal diakses 4 Juni 2009.

$<$ http://www.detiknews.com/read/2008/09/22/144556/1010353/10/hampir-53ribu-anak-sakit-akibat-susu-bermelamine-di-china?nd992203605>, diakses 4 Juni 2009.

$<$ http://www.koran-jakarta.com/berita-detail.php?id=58351>, diakses tanggal 4 Juni 2009.

$<$ http://www.pikiran-rakyat.com/cetak/1103/17/0304.htm>, diakses tanggal 4 Juni 2009. 
<http://www.pikiran-rakyat.com/cetak/1103/17/0304.htm>, diakses tanggal 17 Nopember 2003

$<$ http://www.sarapanpagi.org/kasus-susu-mengandung-melaminevt2329.html>, diakses 4 Juni 2009. 